\title{
Effects of dissolved oxygen and fresh organic matter on the bioturbation potential of macrofauna in sublittoral sediments off Central Chile during the 1997/1998 El Niño
}

\author{
Dimitri Gutiérrez ${ }^{1, *}$, Víctor A. Gallardo ${ }^{1}$, Sergio Mayor ${ }^{1}$, Carlos Neira ${ }^{2}$, \\ Cristian Vásquez ${ }^{1}$, Javier Sellanes ${ }^{1}$, Marcelo Rivas ${ }^{1}$, Aldo Soto ${ }^{1}$, \\ Franklin Carrasco ${ }^{1}$, Mario Baltazar ${ }^{1}$ \\ ${ }^{1}$ Departamento de Oceanografía (Programa FONDAP-Humboldt), Universidad de Concepción, Casilla 160-C, \\ 40831 Concepción, Chile \\ ${ }^{2}$ Institute für Chemie und Biologie des Meeres, Universität Oldenburg, Postfach 2503, 26111 Oldenburg, Germany
}

\begin{abstract}
A study off Concepción, central Chile, during the 1997/1998 El Niño (EN) revealed that the concentration of dissolved oxygen and the organic content and quality of the sediment control the vertical distribution of macrofauna in the sediment and bioturbation potential. The study area, characterized by organic-rich, silty sediments, lies within the most intense upwelling center off the coast of Chile, and is subject to the seasonal influx of hypoxic subsurface waters. Five stations (28 to $120 \mathrm{~m}$ depth) were sampled seasonally. The vertical distribution and integrated biomass and abundance of macrofauna ( $>0.5 \mathrm{~mm}$ ) were determined, as well as the dissolved oxygen content of the bottom water (BWDO) and sediment parameters such as total organic carbon (TOC), the C/N ratio, sulphide content, chl a content, and the thickness of the oxidized zone. Chl a proved to be a good indicator of fresh (highquality) organic matter. Major components contributing to variation in the macrofauna feeding guilds, bioturbation categories, and their vertical position in the sediment were: (1) the relative bioturbation potential (contribution of bioturbating taxa to the assemblage) and (2) the vertical distribution and ratio of surface-to subsurface deposit-feeders. Higher levels of BWDO and a lower quality of organic matter at the sediment surface tended to provide better conditions for potentially strong bioturbators, while lower BWDO levels and higher-quality organic matter were accompanied by the dominance of tube-dwelling, surface-defecating (and hence weakly bioturbating) species. Higher TOC levels and lower-quality organic matter at the surface resulted in deeper vertical distributions of animals and a higher relative abundance of subsurface deposit-feeders. During the study period, BWDO levels increased, while the total organic carbon and the quality of organic matter decreased. These conditions encouraged the vertical penetration of macrofauna into the sediment column and the relatively larger contribution of stronger bioturbators to the assemblage. The most drastic changes in faunal lifestyles and vertical distribution during the 1997/1998 EN were observed within the Bay of Concepción, an area usually characterized by sulphidic sediments under the conditions of severe seasonal hypoxia or anoxia obtaining during 'normal' (i.e. non-EN) years; and in the deepest shelf site, which usually experiences permanent hypoxia because of the influence of the 'oxygen minimum zone'.
\end{abstract}

KEY WORDS: Bioturbation potential $\cdot$ Vertical distribution $\cdot$ Benthos $\cdot$ El Niño $\cdot$ Fresh organic matter Hypoxia $\cdot$ Central Chile $\cdot$ Sublittoral

\section{INTRODUCTION}

Bioturbation, the biogenic reworking of the primary structure of the sediment, affects several processes in

*E-mail: dgutierr@udec.cl the seabed (Smith 1992). Burial and recycling of organic matter (Aller 1982, Sun et al. 1991, Boudreau 1997), preservation of bio-stratigraphies (Wheatcroft 1989), and even the evolution and structure of benthic communities (Hall 1994, Levin et al. 1997a), are some of the potential consequences of bioturbation. 
The increasing use and development of sampling devices (e.g. the multicorer; Barnett et al. 1984) that do not disrupt the vertical zonation of macrofauna, together with a better knowledge of macrofaunal feeding and particle-transport, have led to a variety of methods for assessing the bioturbation potential of the soft-bottom macrofauna (Wheatcroft et al. 1990, Swift 1993, Blake 1994, Grehan et al. 1994, Blair et al. 1996, Levin et al. 1997a, 2000, Dauwe et al. 1998). For example, Swift (1993) and Grehan et al. (1994) measured species abundance by a scoring scale according to feeding mode, mobility, and burrowing capability. It has been hypothesized, however, that bioturbation depends mainly on deposit-feeding rather than on burrowing (Jumars \& Wheatcroft 1989). Dauwe et al. (1998) used feeding behavior and particle-transport behavior to investigate the bioturbation potential of sublittoral locations in the North Sea. The present study assesses bioturbation potential by a combination of observations on feeding and particle-transport and data on macrofauna standing stock.

The effects of hypoxia and anoxia on macrobenthic communities have been studied extensively (Rhoads \& Morse 1971, Levin et al. 1991, Díaz \& Rosenberg 1995). Oxygen deficiency limits macrofaunal abundance, biomass and species' richness. It also affects macrofauna behavior such as tube irrigation and vertical position within the sediment (Díaz \& Rosenberg 1995). Laminated, non-bioturbated sediments are typical of anoxic settings (Rhoads \& Morse 1971). In oligotrophic, deepsea sediments, fresh organic matter input to the sediment triggers rapid particle subduction by macrofauna (Graf 1989).

This study investigated sublittoral soft bottoms off Concepción (ca $36^{\circ} \mathrm{S}$ ) in central Chile. The study area constitutes probably the most intense upwelling center off the Chilean coast, with measured primary production rates of up to $9.9 \mathrm{~g} \mathrm{C} \mathrm{m}^{-2} \mathrm{~d}^{-1}$ during seasonal upwelling events (Fossing et al. 1995). It has been suggested that a large portion of particulate organic carbon is channelled into the sediments (Ahumada 1989). Upwelling events follow a seasonal cycle, with a higher frequency and intensity during spring/summer. In addition, the South Pacific eastern boundary oxygen minimum zone (OMZ) $\left(<0.5 \mathrm{ml} \mathrm{l}^{-1}\right)$ impinges on the continental margin from $\sim 100$ to $300 \mathrm{~m}$ depth (Gallardo et al. 1995). However, during an upwelling event the hypoxic water mass may enter shallow depths $(20 \mathrm{~m}$; Gallardo 1985). In the Bay of Concepción, the continuously elevated primary production of the surface waters and hydrodynamic features of the water body result in very high organic loadings that are reflected in the sulphidic nature of the sediments (Gallardo \& Castillo 1972). Consequently, the bottom-water dissolved oxygen (BWDO) is usually totally depleted dur- ing spring/summer, and mass mortality of infauna may occur (Carrasco 1996). On the shelf, a relatively abundant (compared with other areas), but species-poor, small-bodied, benthic macrobiota inhabits the organicrich sediments. Occasionally this biota includes massive bacterial mats of the filamentous sulfideoxidizing/nitrate-reducing bacterium Thioploca spp. (Gallardo 1977, Gallardo et al. 1995).

The first survey in our study period (May 1997) was made shortly after the onset of the 1997/1998 El Niño (EN) (McPhaden 1999). Off Concepción, a significant rise in the sea-surface temperature anomaly $\left(<1^{\circ} \mathrm{C}\right.$ was estimated for $1 \mathrm{yr}$, beginning in May 1997 (Gallardo et al. unpubl.). The effects of the previous EN on shallow sublittoral communities have been described by Tarazona et al. $(1988,1996)$ for the area off the Peruvian coast. During an EN, the sublittoral benthic subsystem experiences increased BWDO levels through intensification of the poleward undercurrent, or through decreased oxygen consumption in the water column (resulting from decreased primary production in the surface waters), or through a combination of both effects (Arntz \& Fahrbach 1996). In turn, increased BWDO leads to an increase in biomass, density, and diversity of communities in otherwise biota-impoverished hypoxic/anoxic coastal sediments. Deeper shelf communities do not exhibit any significant pattern of increased density or biomass (Arntz et al. 1991). The studies off the coast of Perú did not assess changes in bioturbation or in the vertical distribution of the infauna, but such changes have been predicted (Arntz et al. 1991).

The main goal of the present study was to explore factors that control macrofaunal bioturbation potential and vertical penetration within the sublittoral sediments off Concepcion. We hypothesized that bioturbation potential (i.e. the contribution of bioturbating taxa to the assemblage) and macrofaunal vertical penetration would increase with increasing sediment oxidation. Since dissolved oxygen concentrations in subsurface waters increase under EN conditions, the study period provided an excellent natural background in which to test our hypothesis. A secondary hypothesis was that macrofauna vertical distribution would be skewed deeper in the sediment and bioturbation potential would be enhanced during the course of EN. Our results showed that not sediment oxidation itself, but BWDO and the quality or 'freshness' of the organic matter play a critical role in bioturbation potential. BWDO increased and organic matter quality was severely reduced during EN.

Thus, the goals of this study were to: (1) assess the relationship between macrofaunal bioturbation potential and vertical distribution of macrofauna in the sediment with abiotic factors, (2) assess the effects of 
the 1997/1998 EN on abiotic factors in the sediment; and (3) investigate the effects of the 1997/1998 EN on bioturbation potential and the vertical distribution of soft-bottom macrofaunal communities in the study area.

\section{MATERIALS AND METHODS}

Field work. A total of 5 seasonal sampling cruises (May, August, and November 1997; March and May 1998) were carried out along a depth transect across the continental shelf off central Chile (ca $36^{\circ} \mathrm{S}$ ). The first survey (May 1997) took place shortly after the onset of EN, the final survey (May 1998) shortly before it ended. Five stations, located between $28 \mathrm{~m}$ (Bay of Concepción) and $120 \mathrm{~m}$ depth (continental shelf) were sampled (Fig. 1). The sampling sites were the same as those of the Thioploca-Chile-94 Expedition (Ferdelman et al. 1997). The stations were categorized as: mid-bay, bay-mouth, inner-shelf, middle-shelf, and outer-shelf. Samples were taken from aboard the RV 'Kay Kay' with a gravity Rumohr corer (i.d. = $74 \mathrm{~mm}$ ) and a minimultiple corer (Barnett et al. 1984), Model MC 600 (tube i.d. = $95 \mathrm{~mm}$ ). All cores were subsampled immediately or within $12 \mathrm{~h}$ of collection. Parallel hydrographic casts (for dissolved oxygen, temperature, salinity, and nitrate) were made at each station using Hydrobioss bottles. Bottom temperature, salinity, and

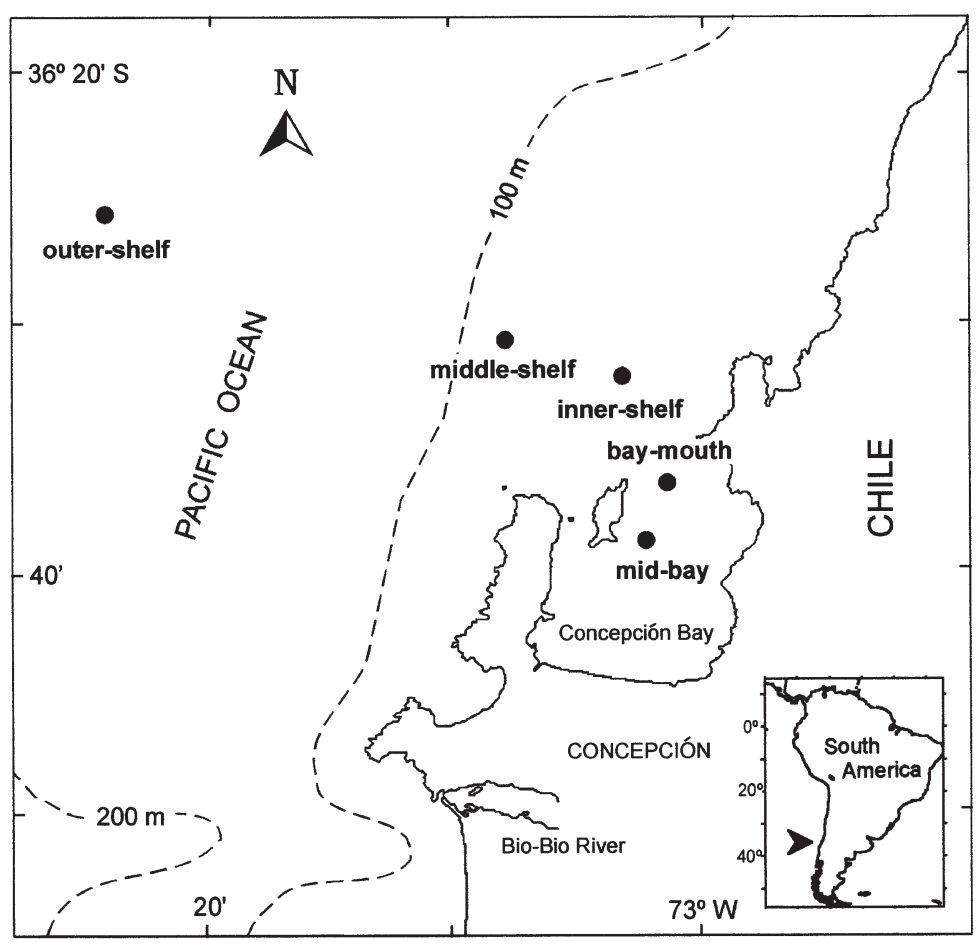

Fig. 1. Locations of sampling sites nitrate data will be presented elsewhere (Gallardo et al. unpubl.). Four independent replicates (1 from each of 4 multicore drops) were made at each station during each season to sample the macrofauna. Vertical sections were sliced at $0-2,2-5,5-10,10-15$, and $15-20 \mathrm{~cm}$ in the original cores. Redox profiles were measured in $74 \mathrm{~mm}$ (i.d.) cores using a platinum standard combination electrode with a calomel internal reference. Subsamples for dissolved sulphide, total organic carbon (TOC), total nitrogen (TN), and chl a were taken with $36 \mathrm{~mm}$ (i.d.) tubes. Sulphides were sampled in 2 independent replicates; chl a was measured in 2 to 3 independent replicates. The other abiotic factors were measured in only 1 core per station.

Laboratory work. Dissolved oxygen was measured in 3 to 6 replicates from Hydrobioss bottles within $12 \mathrm{~h}$ of sampling; the reported values are the lowest obtained within replicates, under the assumption that higher values reflected contamination. The samples were analyzed by the Winkler method as modified from Carpenter's technique (Knap et al. 1993), and microtitrated with a DOSIMAT. The end-point was recorded with a photoelectric cell. TOC and TN were determined from previously lyophilized samples with a CHN elemental analyzer at the University of Oldenburg, Germany. Pore-water was extracted under $\mathrm{N}_{2}$ atmosphere with a pneumatic squeezer at 1 and $2 \mathrm{~cm}$ sections in the first $15 \mathrm{~cm}$ of sediment. Sulphides were determined colorimetrically following Cline (1969). Samples were fixed with $2 \%$ zinc acetate until analysis (within $1 \mathrm{mo}$ ). Inventories of sulphide were calculated by correcting for porosity and integrating the first $15 \mathrm{~cm}$ of sediment.

Chlorophyll a (chl a)and phaeopigments were analyzed fluorometrically in a sediment section of 0 to $1 \mathrm{~cm}$. The fluorometric acidification method does not discriminate between chl a, chl a allomers, and chlorophyllide a. Samples were kept frozen at $-20^{\circ} \mathrm{C}$ and thawed before extraction. Thawed fractions of 0.2 to $0.3 \mathrm{~g}$ were mixed with $5 \mathrm{ml}$ of $90 \%$ acetone on a vortex stirrer, sonicated for $10 \mathrm{~min}$ and then centrifuged at $1500 \times g$ for $5 \mathrm{~min}$. This extraction was done twice. A $0.5 \mathrm{ml}$ aliquot of the pooled extract was diluted 20 times to obviate interferences arising from the high levels of phaeopigments and carotenoids, and fluorescence was then read before and after acidification with 2 drops of $10 \% \mathrm{HCl}$. The appropiate dilution was determined by measuring the fluorometric responses of different dilutions of a sediment extract spiked with standard chl a 
(Sigma) versus the fluorometric responses of the same extract with no standard chl a added. Water content and dry-density data from parallel samples were used to express the results on a dry weight basis $\left(\mathrm{mg} \mathrm{g}^{-1}\right)$. To further characterize the quality of organic matter, ratios of chl a concentrations to TOC contents (in $\mathrm{mg}$ chl a $\mathrm{mg}^{-1} \mathrm{C}$ ) were calculated.

The macrofauna $(>0.5 \mathrm{~mm}$ ) was sorted to the lowest possible taxon. Taxa were assigned to feeding guilds based on: (1) literature (Fauchald \& Jumars 1979, Dauer 1985, Josefson 1986, Gaston 1987, Carrasco \& Oyarzún 1988, Swift 1993, Grehan et al. 1994, Maurer et al. 1994, Levin et al. 1997a, 1999); (2) personal observations of the behavior of animals in a flume system, and (3) in some cases their vertical distribution. Feeding guilds considered were interface-feeders (IF), which are able to switch from suspension-feeding to surface deposit-feeding (Josefson 1986, Taghon \& Greene 1993, Dauwe et al. 1998); surface depositfeeders (SDF); subsurface deposit-feeders (SSDF); suspension-feeders $(\mathrm{SF})$; and omnivores/predators (OP). In addition, taxa were grouped in bioturbation categories following Dauwe et al. (1998). Categories were defined as: surface defecators (SD), which includes spionids and amphipods; diffusion bioturbators (Diff), which comprise most endobenthic predators, and small surface and subsurface deposit-feeders that transport particles locally and non-directionally; conveyor-belt feeders (CBF), which are head-down deposit-feeders that defecate or transport particles to the surface; reverse conveyor-belt feeders (RCB), which include deposit-feeders that feed on the surface and defecate at subsurface levels as well as headdown deposit-feeders that subduct surface particles such as Maldanidae; and carnivores/sessiles (CS) (Wheatcroft et al. 1990, Levin et al. 1997a, Dauwe et al. 1998).

Statistical analyses. Parametric and nonparametric ANOVAs were used to assess spatial and temporal changes in macrofauna parameters and abiotic factors. The Kruskal-Wallis ANOVA was employed when data could not be transformed to a normal distribution. If there were significant changes $(\alpha<0.05)$, the MannWhitney $U$-test was used for contrasts. Spatial changes in macrofaunal attributes (vertical distribution, feeding guilds and bioturbation categories) were examined, pooling all the data (with a few exceptions, as noted in the relative sections). For chemical parameters with non-replicated measurements, a Friedman ANOVA was used to assess temporal changes, using stations as blocks (Sokal \& Rohlf 1998).

To reveal the main spatial and temporal patterns of abiotic factors and to examine the relationships between them, a principal components analysis (PCA) was carried out on most of the data. Because of the dif- ferent units used for the abiotic factors, eigenvalues were computed from a correlation matrix. PCA was also used to examine the relationships between percent contributions to total density and total biomass by feeding guilds, bioturbation categories, and vertical position of the macrofauna in the sediment. In this case, eigenvalues were obtained from a variancecovariance matrix. PC1 and PC2 obtained from biological data were interpreted and then used as dependent variables in a multiple regression with abiotic factors as independent variables. The best model was obtained by combining step-wise procedures and manual selection of independent variables possessing higher correlations with the dependent variables (Legendre \& Legendre 1983, James \& McCulloch 1990). All analyses were performed with STATISTICA 5.1 and SPLUS 4.5 statistical softwares.

\section{RESULTS}

\section{Macroscopic characteristics of sediments}

All sites were characterized as silty sediments (ca $95 \%$ ); grain size corresponded to medium silt, and the particles were moderately sorted and negatively asymmetric. There were no significant differences in sediment grain-size, sorting or symmetry among stations or cruises. Also, there were no significant differences in those parameters among sediment layers within each station (data not shown). The total organic matter at the surface (determined by weight loss on ignition) exhibited values $>10 \%$ in all cases. In the mid-bay, sediments that in May 1997 were black and sulphidic from the first centimeter downward turned brown at the sediment-water interface from August 1997 onwards. At the bay-mouth and inner- and middleshelf sites, sediments were brown throughout the sediment column. At the outer-shelf site, the top 10 to $15 \mathrm{~cm}$ of sediment was olive-green.

\section{Abiotic factors \\ Oxygen}

Spatially, lower values were recorded for the deeper stations (middle and outer-shelf), and ranged from 0.19 to $1.39 \mathrm{ml} \mathrm{l}^{-1}$. At the shallower sites (bay and inner-shelf), BWDO tended to be higher and much more variable, (0.28 to $5.20 \mathrm{ml} \mathrm{l}^{-1}$; Fig. 2a-e). Normoxic conditions ( $>2 \mathrm{ml} \mathrm{l}^{-1}$ ) were recorded for the shallower sites from May to November 1997. Here, temporal changes were significant (Friedman ANOVA $\chi^{2}{ }_{4}=9.87 ; \mathrm{p}=0.042$ ) and clearly seasonal, 

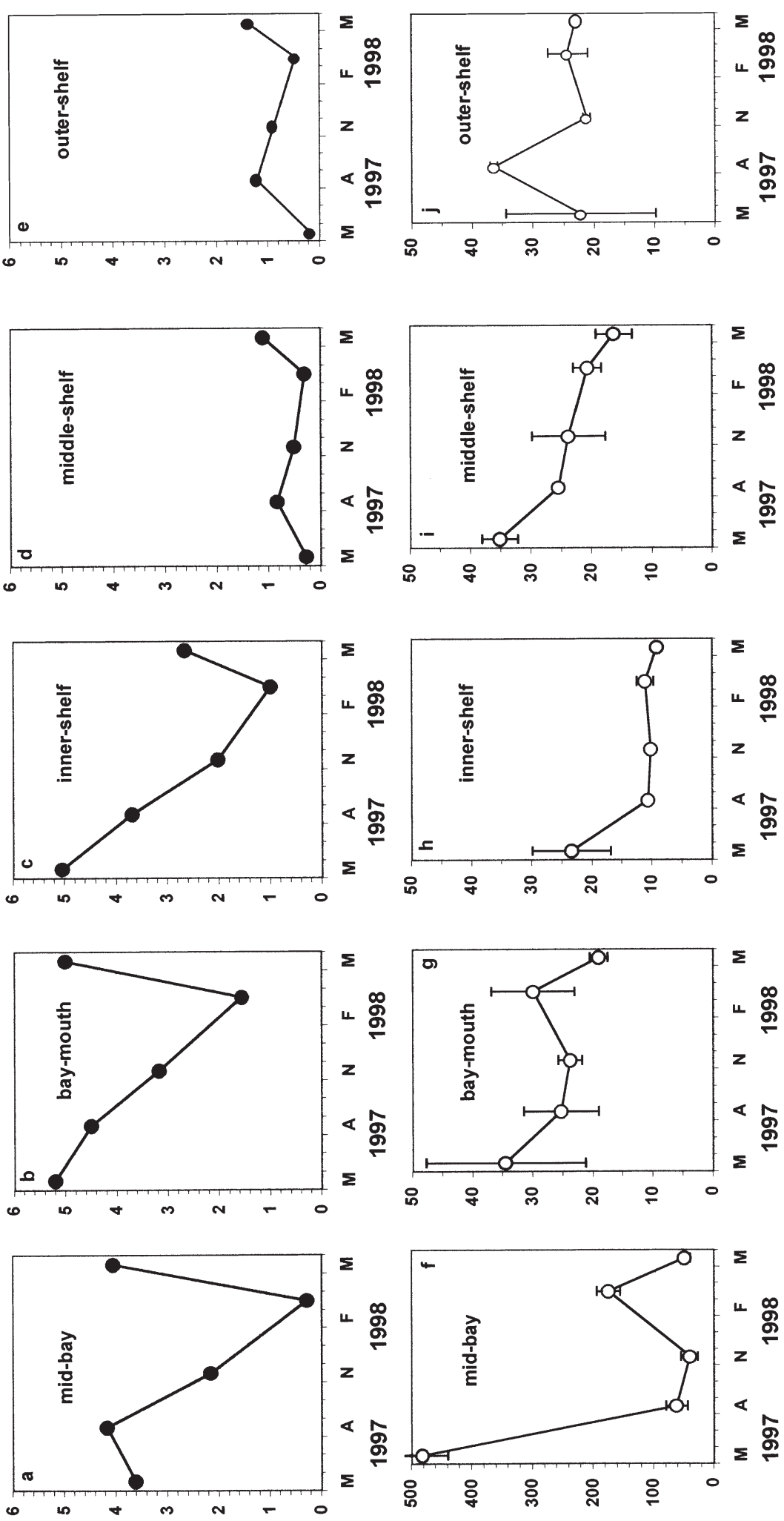

Bottom-water dissolved oxygen $\mathrm{ml} \mathrm{l}^{-1}$

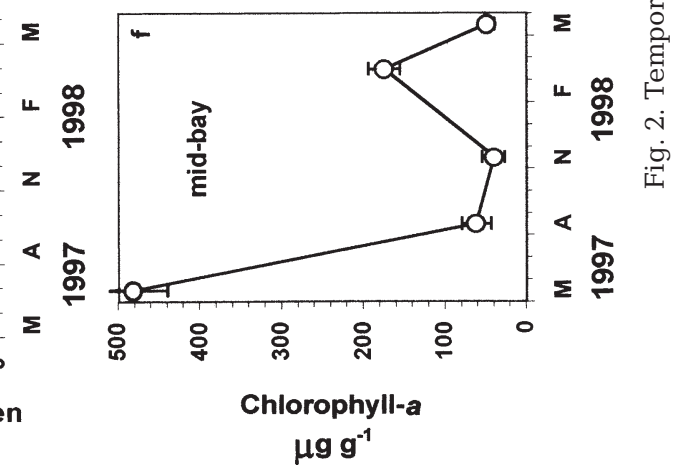

with lower levels in summer (March 1998) and higher levels in autumn/ winter (May 1997/98, August 1997). At the deeper sites, lower levels were determined in May 1997 (<0.3 $\mathrm{ml} \mathrm{l}^{-1}$ ) and higher levels in May 1998 (>1.1 $\mathrm{ml} \mathrm{l}^{-1}$ ).

\section{Redox potential}

The oxidized zone, OZ $(E h>0)$ was narrowest and least variable at the mid-bay site (1-2 cm). Outer-shelf sediments showed the greatest OZ extension on average $(5-12 \mathrm{~cm})$. Overall temporal changes were significant (Friedman ANOVA $\chi_{4}^{2}=10.65 ; \mathrm{p}=$ 0.031), with the narrowest OZ extensions measured in August and November of 1997 and the widest in March 1998. The redox potential in the first centimeter $\left(E h_{z 0}\right)$ increased with increasing station depth. In the midbay, $E h_{z 0}$ values increased slightly from $-23 \mathrm{mV}$ to $+67 \mathrm{mV}$ during the study period. On the outer-shelf, values were fairly constant (>150 mV) throughout the study period (Table 1).

\section{Total organic carbon and $\mathrm{C} / \mathrm{N}$ ratios}

Surface-sediment TOC values (15.1 to $55.5 \mathrm{mg} \mathrm{g}^{-1}$ ) showed an inverse parabolic pattern with water depth, especially at the beginning of the study. TOC concentrations at the 10 to $15 \mathrm{~cm}$ level were still high, in the range of 21.6 to $44.7 \mathrm{mg} \mathrm{g}^{-1}$ (Table 1). Pooling of data from all cruises, revealed very significant spatial (Kruskal-Wallis $H$ statistic, ANOVA $H_{4,25}=17.39, \mathrm{p}=$ 0.002) differences in surface TOC among the stations, with the lowest contents in the inner-shelf, and the highest ones in the mid-bay and in the outer-shelf. Temporal changes in surface TOC (Friedman ANOVA $\chi_{4}^{2}=$ 9.12; $\mathrm{p}=0.058$ ) included a reduction of TOC contents in May 1998 compared to May 1997. C/N ratios at the surface varied from 6.1 to 10.2 , while $\mathrm{C} / \mathrm{N}$ ratios at 10 to $15 \mathrm{~cm}$ varied from 7.9 to 12.7 (Table 1). 
Table 1. Raw data for abiotic factors in sediment. $\mathrm{TOC}_{z 0}=$ total organic carbon at surface $(0-1 \mathrm{~cm}) ;$ TOC $\mathrm{d}=$ total organic carbon at depth $(10-15 \mathrm{~cm}) ;$ Ratio = ratio chl a/TOC at surface; $\mathrm{C} / \mathrm{N}_{z 0}=$ ratio carbon/nitrogen at surface; $\mathrm{C} / \mathrm{N}_{\mathrm{d}}=$ ratio carbon/nitrogen at depth $(10-15 \mathrm{~cm}) ; \Sigma \mathrm{H}_{2} \mathrm{~S}=$ pool of sulphides; $E h_{z 0}=$ redox potential at surface; $\mathrm{OZ}=$ thickness of oxidized zone $(E h>0 \mathrm{mV})$

\begin{tabular}{|c|c|c|c|c|c|c|c|c|c|c|}
\hline Station & $\begin{array}{l}\text { Depth } \\
\text { (m) }\end{array}$ & Cruise & $\begin{array}{c}\mathrm{TOC}_{z 0} \\
\left(\mathrm{mg} \mathrm{g}^{-1}\right)\end{array}$ & $\begin{array}{c}\mathrm{TOC}_{\mathrm{d}} \\
\left(\mathrm{mg} \mathrm{g}^{-1}\right)\end{array}$ & $\begin{array}{c}\text { Ratio } \\
\left(\mu \mathrm{g} \mathrm{mg} \mathrm{C}^{-1}\right)\end{array}$ & $\begin{array}{c}\mathrm{C} / \mathrm{N}_{z 0} \\
(\mathrm{~mol} / \mathrm{mol})\end{array}$ & $\begin{array}{c}\mathrm{C} / \mathrm{N}_{\mathrm{d}} \\
(\mathrm{mol} / \mathrm{mol})\end{array}$ & $\begin{array}{c}\sum \mathrm{H}_{2} \mathrm{~S} \\
\left(\mathrm{mmol} \mathrm{m}^{-2}\right)\end{array}$ & $\begin{array}{l}E h_{z 0} \\
(\mathrm{mV})\end{array}$ & $\begin{array}{l}\mathrm{OZ} \\
(\mathrm{cm})\end{array}$ \\
\hline \multirow[t]{5}{*}{ Mid-bay } & \multirow[t]{5}{*}{$(29)$} & May 1997 & 49.9 & 34.3 & 9.65 & 7.89 & 8.93 & 192.38 & -23 & 1 \\
\hline & & Aug 1997 & 33.4 & 27.6 & 1.85 & 8.84 & 10.41 & 16.89 & -13 & 1 \\
\hline & & Nov 1997 & 35.2 & 33.8 & 1.15 & 8.21 & 8.11 & 23.23 & -20 & 1 \\
\hline & & Mar 1998 & 49.3 & 33.6 & 3.54 & 7.47 & 9.21 & 15.09 & 41 & 2 \\
\hline & & May 1998 & 34.6 & 32.0 & 1.40 & 7.34 & 7.85 & 11.44 & 67 & 2 \\
\hline \multirow[t]{5}{*}{ Bay-mouth } & \multirow[t]{5}{*}{ (35) } & May 1997 & 31.9 & 22.0 & 1.08 & 8.27 & 10.07 & 1.89 & 189 & 10 \\
\hline & & Aug 1997 & 32.1 & 21.7 & 0.79 & 7.62 & 12.73 & 2.05 & 101 & 5 \\
\hline & & Nov 1997 & 35.8 & 29.1 & 0.66 & 8.35 & 8.59 & 1.14 & 36 & 2 \\
\hline & & Mar 1998 & 36.9 & 28.9 & 0.81 & 7.83 & 10.00 & 2.21 & 121 & 6 \\
\hline & & May 1998 & 31.5 & 29.8 & 0.60 & 8.35 & 9.17 & 3.23 & 149 & 6 \\
\hline \multirow[t]{5}{*}{ Inner-shelf } & \multirow[t]{5}{*}{ (64) } & May 1997 & 29.9 & 24.3 & 0.78 & 9.17 & 10.31 & 1.10 & 251 & 9 \\
\hline & & Aug 1997 & 15.1 & 21.6 & 0.70 & 6.09 & 10.06 & 1.45 & 66 & 4 \\
\hline & & Nov 1997 & 30.1 & 27.5 & 0.34 & 10.03 & 10.37 & 0.77 & 100 & 7 \\
\hline & & Mar 1998 & 26.7 & 26.1 & 0.42 & 8.65 & 10.25 & 2.08 & 123 & 9 \\
\hline & & May 1998 & 25.3 & 23.2 & 0.36 & 10.18 & 10.43 & 2.53 & 168 & 5 \\
\hline \multirow[t]{5}{*}{ Middle-shelf } & \multirow[t]{5}{*}{ lf $(88)$} & May 1997 & 37.6 & 29.2 & 0.94 & 8.12 & 8.64 & 3.63 & 302 & 12 \\
\hline & & Aug 1997 & 27.9 & 27.8 & 0.91 & 8.43 & 8.27 & nd & 117 & 2 \\
\hline & & Nov 1997 & 33.5 & 32.1 & 0.71 & 8.68 & 8.99 & 1.00 & 126 & 3 \\
\hline & & Mar 1998 & 37.5 & 38.2 & 0.55 & 7.95 & 8.7 & 2.70 & 195 & 9 \\
\hline & & May 1998 & 36.1 & 31.0 & 0.45 & 8.60 & 8.83 & 3.15 & 86 & 7 \\
\hline \multirow[t]{5}{*}{ Outer-shelf } & \multirow[t]{5}{*}{ (121) } & May 1997 & 50.0 & 35.8 & 0.44 & 8.33 & 10.22 & 0.83 & nd & 10 \\
\hline & & Aug 1997 & 50.9 & 39.3 & 0.72 & 7.23 & 10.32 & 1.14 & 175 & 5 \\
\hline & & Nov 1997 & 47.0 & 40.4 & 0.45 & 8.31 & 9.56 & 0.76 & 165 & 11 \\
\hline & & Mar 1998 & 55.5 & 44.7 & 0.44 & 7.99 & 9.63 & 2.25 & 158 & 11 \\
\hline & & May 1998 & 46.9 & 40.1 & 0.49 & 8.42 & 9.62 & 2.84 & 178 & 12 \\
\hline
\end{tabular}

\section{Chlorophyll a}

Sediment-surface chl a concentrations in the midbay varied from 40.5 to $481.7 \mathrm{\mu g} \mathrm{g}^{-1}$ throughout the study period (equivalent to 9.6 to $37.4 \mu \mathrm{g} \mathrm{cm}^{-3}$ ). Chl a concentrations at the remaining sites varied from 9.2 to $37.5 \mu^{-1} \mathrm{~g}^{-1}$ (4.1 to $10.2 \mu \mathrm{g} \mathrm{cm}^{-3}$ ). A 2-way ANOVA for cruise and sampling site effects on the logs of chl a revealed significant differences among cruises $\left(F_{4,28}=\right.$ $22.15, \mathrm{p}<0.00001)$ and among stations $\left(F_{4,28}=108.23\right.$, $\mathrm{p}<0.00001)$. Spatially, higher values were determined in the mid-bay and lower concentrations in the innershelf areas. Temporally, higher concentrations were measured in May 1997 and lower concentrations in November 1997 and May 1998. Surface chl a to TOC

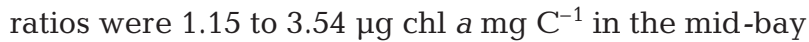
and 0.36 to $1.01 \mu \mathrm{g} \mathrm{chl} \mathrm{a} \mathrm{mg} \mathrm{C}^{-1}$ in the remaining stations. Spatial and temporal variations in the ratios were similar to those in the chl a concentrations (Fig. 2f-j).

\section{Sulphides}

In the mid-bay, concentrations $>1500 \mu \mathrm{M}$ in the porewater were recorded in May 1997, decreasing to $\sim 300 \mu \mathrm{M} 1$ yr later. Sulphide concentrations were low $(<50 \mu \mathrm{M})$ in the remaining sites throughout the study period. Sulphide $\left(\Sigma_{\mathrm{H}_{2} \mathrm{~S}}\right)$ pools were higher in the midbay sediments, ranging from 11.4 to $192.4 \mathrm{mmol} \mathrm{m}^{-2}$. The pools ranged from 0.8 to $3.6 \mathrm{mmol} \mathrm{m}^{-2}$ in the other sites (Table 1). The 2 -way ANOVA revealed significant differences among cruises $\left(F_{4,24}=3.04, \mathrm{p}=0.037\right)$ and among stations $\left(F_{4,24}=49.99, \mathrm{p}<0.00001\right)$. Higher pools were determined in May 1997 and lower inventories in November 1997.

\section{Temporal patterns}

The PCA of abiotic factors revealed that $63 \%$ of the variance from all the original variables was explained by the 2 first PCs (Table 2). PC1 indicated a negative relationship between the quality of organic matter (chl $a$, chl a/TOC ratio, sulphide inventories) and the oxidative state of the sediment ( $E h_{z 0}$ and OZ). PC2 related low BWDO values to high TOCs and vice versa (Table 2). Three distinct temporal patterns are noticeable. In the mid-bay and in the inner-shelf, lower BWDO and higher TOC were present in May 1997 and March 1998, with a very high organic qual- 
Table 2. Loadings for PCA based on abiotic factors. Eigenvalue percentages instead of percentages of explained variance are given since correlation matrix was used for PCA. Abbreviations as in legend to Table $1 ; \ln$ = natural logarithm; BWDO = bottom-water dissolved oxygen

\begin{tabular}{|lcc|}
\hline Variable & PC1 & PC2 \\
\hline $\ln \left(\sum_{\left.\mathrm{H}_{2} \mathrm{~S}\right)}\right.$ & -0.91 & 0.02 \\
$\mathrm{BWDO}$ & -0.15 & -0.74 \\
$\mathrm{TOC}$ & 0.83 \\
$\ln (\mathrm{chl} a)$ & -0.30 & 0.32 \\
$\mathrm{C} / \mathrm{N}_{z 0}$ & -0.87 & -0.15 \\
$\mathrm{C} / \mathrm{N}_{\mathrm{d}}$ & 0.36 & -0.28 \\
Eh & 0.36 & 0.37 \\
$\mathrm{OZ}$ & 0.73 & 0.52 \\
Ratio & 0.71 & 0.09 \\
Eigenvalues (\%) & -0.91 & 21 \\
& 43 & \\
\hline
\end{tabular}

ity in the mid-bay. In the bay-mouth, seasonal variations were observed, with higher levels of BWDO and sediment oxidation in autumn and winter, and lower values of BWDO and less-oxidized, 'fresher' sediment in spring and summer. In the inner and outer-shelf, there were no marked temporal changes. In the former case, high BWDO levels prevailed and sediments were oxidized with a relatively low quantity and quality of organic matter; in the latter case, hypoxic condi- tions dominated and sediments were also oxidized, with a high quantity but low quality of organic matter (Fig. 3).

\section{Biological data}

Species composition, feeding guilds and bioturbation categories

A total of 62 species/morphs of macrofauna ( $>0.5 \mathrm{~mm}$ ) were recorded during the study period. Polychaetes were the dominant group (with 32 species/ morphs), followed by molluscs (8 species) and crustaceans (6 species). Among the feeding guilds, omnivores/predators were the dominant group (19 species), followed by surface deposit-feeders (17 species), subsurface deposit-feeders (13 species), interface-feeders (6 species), and suspension-feeders (4 species). Among the bioturbation categories, diffusive bioturbators dominated with 30 species/morphs, followed by surface defecators (18 species), reverse conveyor-belt feeders ( 7 species), conveyor-belt feeders (4 species) and carnivores/sessiles (1 species). Table 3 shows the mean densities of the most abundant species collected in the study. The polychaete Paraprionospio pinnata was the primary dominant species (pooled data), and attained its highest numbers in the mid-bay site.

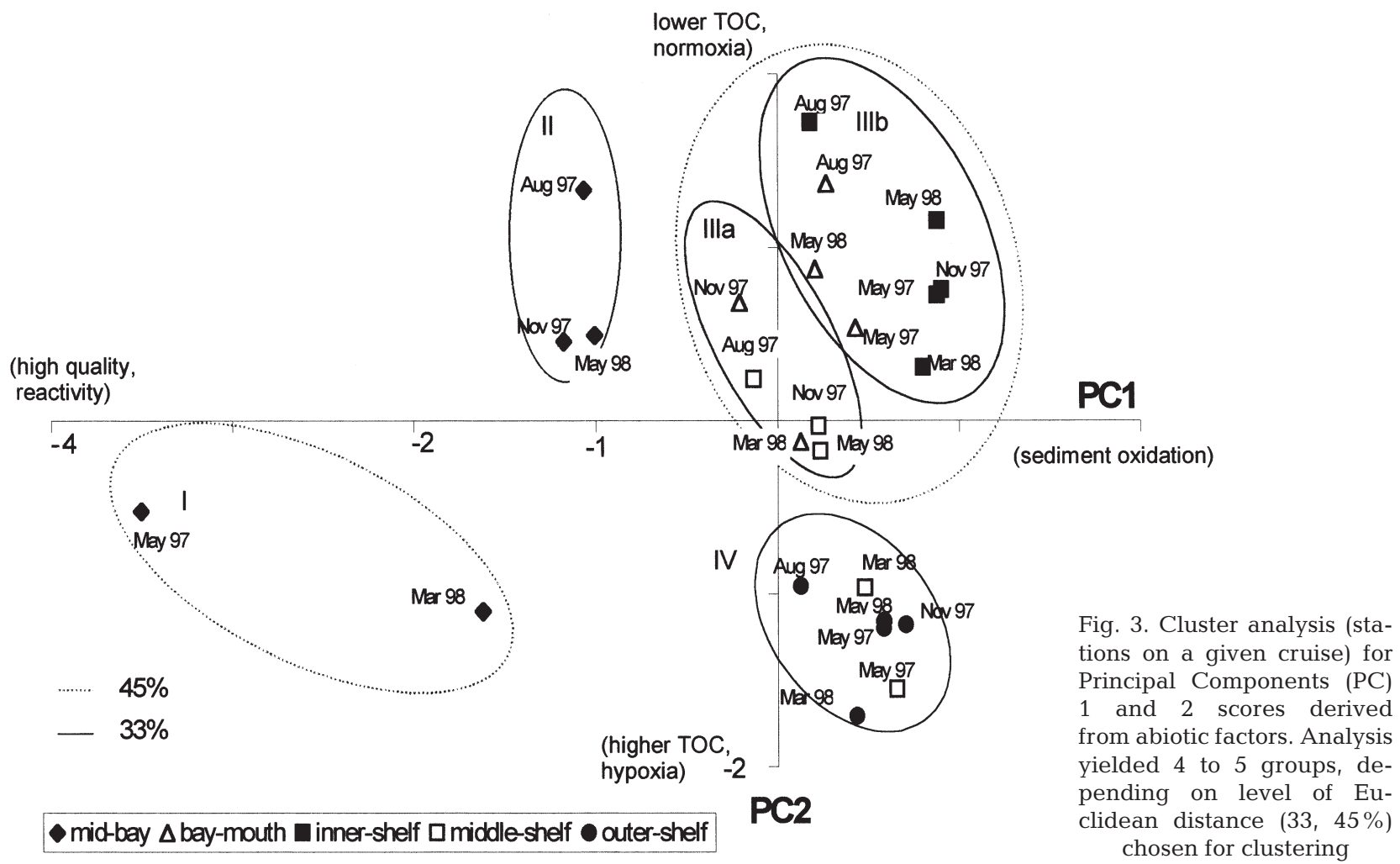


Table 3. Mean densities (individuals $\mathrm{m}^{-2}$; rounded values) of the numerically dominant species $(>0.1 \%)$ of the 5 sampling sites. $\mathrm{SDF}=$ surface deposit-feeders; IF = interface-feeders; $\mathrm{OP}=$ omnivores/predators; SSDF $=$ subsurface deposit-feeders; $\mathrm{SF}=\mathrm{sus}-$ pension-feeders. $\mathrm{BC}$ (bioturbation categories): $\mathrm{CBF}=$ conveyor-belt feeders; Diff $=$ diffusive bioturbators; $\mathrm{RCB}=$ reverse conveyor-belt feeders; $\mathrm{SD}=$ surface-defecators; $\mathrm{P}=$ polychaeta $\mathrm{C}=$ crustacea $\mathrm{M}=$ mollusca; $\mathrm{O}=$ others

\begin{tabular}{|c|c|c|c|c|c|c|c|c|c|c|}
\hline \multirow{2}{*}{$\begin{array}{l}\text { Feeding } \\
\text { guild }\end{array}$} & \multirow{2}{*}{$\begin{array}{l}\text { Biotur- } \\
\text { bation } \\
\text { category }\end{array}$} & \multirow{2}{*}{\multicolumn{2}{|c|}{ Taxa }} & \multicolumn{5}{|c|}{ Sampling sites } & \multicolumn{2}{|c|}{ Average } \\
\hline & & & & $\begin{array}{l}\text { Mid- } \\
\text { bay }\end{array}$ & $\begin{array}{l}\text { Bay- } \\
\text { mouth }\end{array}$ & $\begin{array}{c}\text { Inner- } \\
\text { shelf }\end{array}$ & $\begin{array}{l}\text { Middle- } \\
\text { shelf }\end{array}$ & $\begin{array}{c}\text { Outer- } \\
\text { shelf }\end{array}$ & Mean & (SD) \\
\hline IF & SD & $\mathrm{P}$ & Paraprionospio pinnata & 16000 & 9300 & 12800 & 9900 & 6800 & 11000 & $(3500)$ \\
\hline SDF & $\mathrm{RCB}$ & $\mathrm{P}$ & Aricidea pigmentata & 3800 & 19000 & 12300 & 300 & 200 & 7100 & $(8300)$ \\
\hline SSDF & Diff & $\mathrm{P}$ & Cossura chilensis & 150 & 6600 & 5100 & 5500 & 7700 & 5000 & $(2900)$ \\
\hline SDF & Diff & $\mathrm{P}$ & Mediomastus branchiferus & 1600 & 11200 & 13600 & 50 & 50 & 5300 & $(6600)$ \\
\hline SSDF & $\mathrm{CBF}$ & $\mathrm{P}$ & Haploscoloplos. kg. chilensis & 2100 & 1200 & 0 & 0 & 0 & 700 & $(1000)$ \\
\hline $\mathrm{OP}$ & Diff & $\mathrm{P}$ & Nephtys ferruginea & 800 & 700 & 300 & 500 & 800 & 600 & $(200)$ \\
\hline OP & Diff & $\mathrm{P}$ & Sigambra bassi & 50 & 100 & 600 & 500 & 150 & 300 & $(300)$ \\
\hline $\mathrm{OP}$ & Diff & $\mathrm{P}$ & Nereis dorsolobata & 100 & 400 & 200 & 10 & 0 & 150 & (150) \\
\hline OP & Diff & $\mathrm{P}$ & Lumbrineridae indet. & 700 & 1300 & 600 & 0 & 0 & 500 & $(500)$ \\
\hline SSDF & Diff & $\mathrm{P}$ & Magelona phyllisae & 30 & 200 & 800 & 400 & 400 & 350 & $(300)$ \\
\hline OP & Diff & $\mathrm{P}$ & Anaitides longipes & 500 & 60 & 40 & 0 & 0 & 100 & $(200)$ \\
\hline OP & Diff & $\mathrm{P}$ & Eteone aestuarina & 70 & 150 & 10 & 0 & 0 & 50 & $(50)$ \\
\hline SF & $\mathrm{RCB}$ & $\mathrm{P}$ & Megalomma monoculata & 800 & 200 & 30 & 0 & 0 & 200 & $(300)$ \\
\hline SSDF & Diff & $\mathrm{P}$ & Ninoe chilensis & 200 & 50 & 30 & 10 & 0 & 60 & (80) \\
\hline SDF & $\mathrm{RCB}$ & $\mathrm{P}$ & Isolda viridis & 30 & 90 & 120 & 0 & 0 & 50 & (50) \\
\hline IF & $\mathrm{SD}$ & $\mathrm{C}$ & Ampelisca araucana & 800 & 3100 & 12900 & 3200 & 20 & 4000 & $(5200)$ \\
\hline IF & SD & $\mathrm{C}$ & Oedicerotidae indet. & 90 & 150 & 40 & 10 & 0 & 60 & (60) \\
\hline SDF & SD & M & Macoma sp. & 500 & 200 & 200 & 0 & 0 & 200 & (200) \\
\hline DF & SD & M & Thyasira tomeana & 90 & 70 & 40 & 0 & 0 & 40 & (40) \\
\hline DF & $\mathrm{SD}$ & M & Nuculana cuneata & 90 & 0 & 80 & 20 & 0 & 40 & (40) \\
\hline OP & Diff & M & Nassarius gayi & 10 & 300 & 10 & 0 & 0 & 60 & (150) \\
\hline SSDF & Diff & $\mathrm{O}$ & Oligochaeta indet. & 10 & 300 & 30 & 0 & 0 & 70 & (150) \\
\hline $\mathrm{SF}$ & $\mathrm{SD}$ & $\mathrm{O}$ & Anthozoa indet. & 700 & 0 & 0 & 0 & 0 & 140 & $(300)$ \\
\hline Total & & & & 29600 & 55500 & 60000 & 20500 & 16400 & 36400 & (20100) \\
\hline
\end{tabular}

Total density and total biomass

Mean values for total density ranged from 7900 to 111500 individuals $\mathrm{m}^{-2}$, with the smallest value recorded in the mid-bay (May 1997) and the highest in the inner-shelf (August 1997). Box-and-whisker plots showed that density increased in the mid-bay and decreased in the middle and outer-shelf sites from May 1997 to May 1998 (Fig. 4a). Spatial variation was statistically significant in all cruises (all Kruskal-Wallis ANOVAs with $\mathrm{p}<0.01$ ), with the highest abundances in the bay-mouth and in the inner-shelf. Mean total biomass values fluctuated between $\sim 12 \mathrm{~g} \mathrm{~m}^{-2}$ and almost $340 \mathrm{~g} \mathrm{~m}^{-2}$, these values being recorded in May 1997 in the mid-bay and in the inner-shelf sites, respectively. In the mid-bay site, biomass increased by $>1$ order of magnitude during the study period (Fig. 4b).

\section{Vertical and horizontal distribution of the main macrofaunal species}

The mean vertical distributions of counts $(+\mathrm{SD})$ of the main macrofauna species, all polychaetes, are shown in Fig. 5. Paraprionospio pinnata, a surface defecator (Dauer 1985), peaked in the top $2 \mathrm{~cm}$, although its main distribution is down to $5 \mathrm{~cm}$. The paraonid Aricidea pigmentata, a surface depositfeeder, was also mainly distributed in the first $5 \mathrm{~cm}$, with a tendency to peak at the 2-5 cm level. Paraonids have been found to behave as reverse conveyor-belt feeders (Levin et al. 1999) Mediomastus branchiferus, a capitellid, was found mainly in the first $2 \mathrm{~cm}$, and therefore we consider it a surface deposit-feeder. Cossura chilensis was found mainly in the $5-10 \mathrm{~cm}$ level, so we include this species in the subsurface deposit-feeding guild, as did Fauchald \& Jumars (1979). The nephtyid Nephtys ferruginea and the pilargid Sigambra bassi are relatively large polychaetes with jaws, and they both displayed a fairly homogeneus distribution in the sediment column. A. pigmentata and $M$. branchiferus peaked in the baymouth and in the inner-shelf sites, while C. chilensis and $S$. bassi increased offshore. $P$. pinnata was abundant in all sites at the beginning of the study; later, its density decreased in the bay-mouth and in the shelf sites but increased in the mid-bay site (data not shown). 

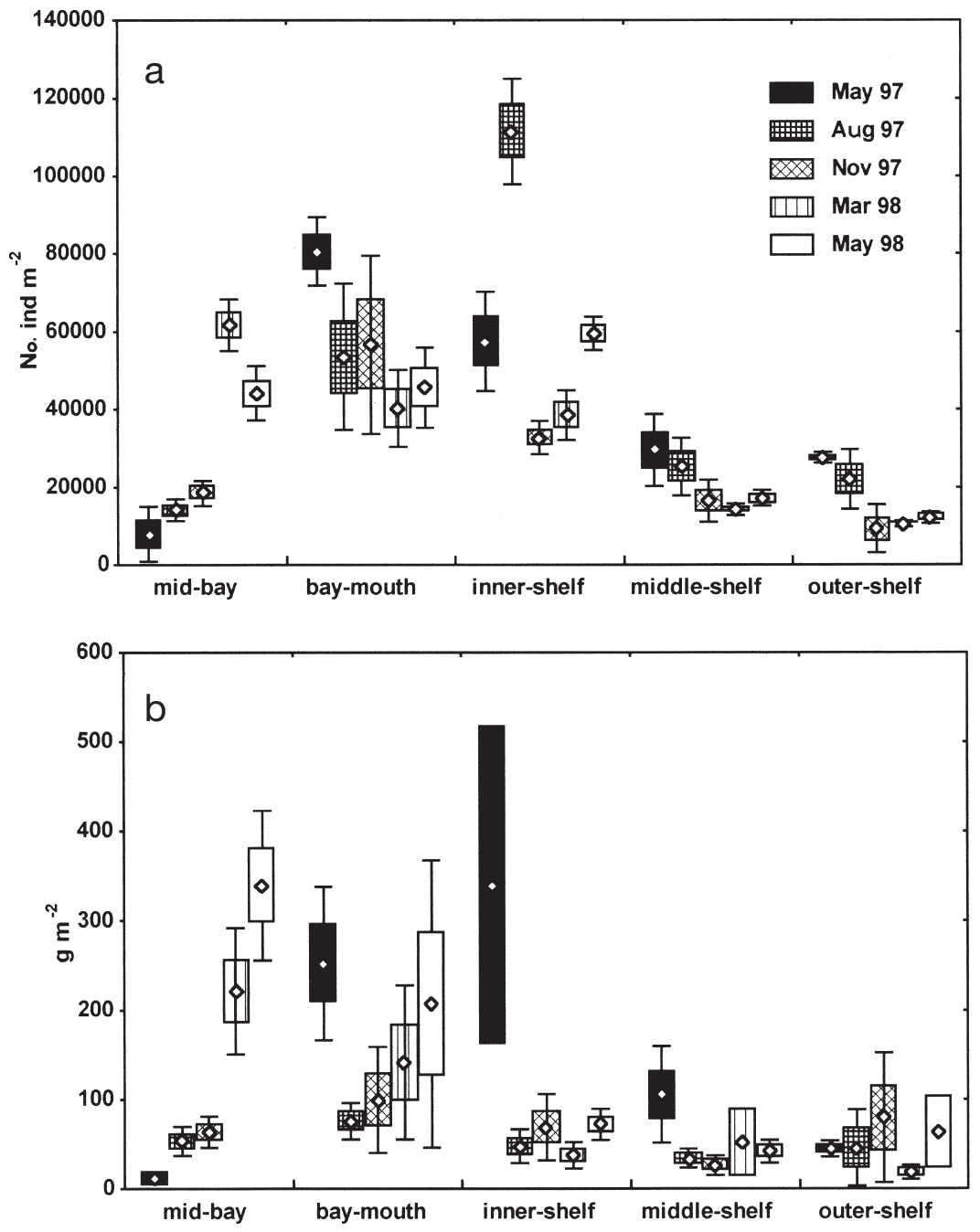

Fig. 4. Spatial and temporal variations of (a) total density and (b) total biomass (wet wt). Data presented as mean \pm 1 SE (boxes) or \pm 1 SD (whiskers) middle and outer-shelf (all Mann-Whitney $U$-tests with $\mathrm{p}<0.001)$. Moreover, the percentage of interface feeders (IF) was higher (all Mann-Whitney $U$-tests with $\mathrm{p}<0.05$ ) in the mid-bay and in the middle-shelf (Fig.7a-e). As the biomasses of the feeding guilds, expressed as percentage, showed a generally similar pattern the data are not shown. An exception was the higher contribution of omnivores/predators (OP), which constituted the second dominant group, after the interface feeders.

The dominant bioturbation categories were surface defecators (SD) and diffusive bioturbators (Diff), both with a numerical abundance mainly in the range of 2000 to 40000 individuals $\mathrm{m}^{-2}$ (20 to $80 \%$ ) (Fig. 7f-j). Reverse conveyor-belt feeders (RCB) reached higher dominances in the bay-mouth and in the inner-shelf (all Mann-Whitney $U$-tests with $\mathrm{p}<0.003$ ), while conveyor-belt feeders (CBF) were more abundant in the mid-bay from August 1997 onwards than in other sites (Mann-Whitney $U$-tests with $\mathrm{p}<0.001)$. The percentage of diffusive bioturbators (Diff) was highest in the outer-shelf (all MannWhitney $U$-tests with $\mathrm{p}<0.001$ ). Spatial changes of surface defecators (SD) were similar to those of interface feeders (IF). The biomass contributions of the various categories, in terms of percentage, followed the same general spatial pattern.
Spatial changes in vertical distribution, feeding guilds and bioturbation categories

In most cases, individuals were concentrated in the first $5 \mathrm{~cm}(\sim 40$ to $80 \%$ at $0-2 \mathrm{~cm}$ and $\sim 20$ to $40 \%$ at $2-5 \mathrm{~cm}$; Fig. 6a-e). The percentages found below $5 \mathrm{~cm}$ were higher in the middle and outer-shelf than in the other sites (all Mann-Whitney $U$-tests with $\mathrm{p}<0.001$ ). In terms of biomass, the percentages at $0-2 \mathrm{~cm}$ and at $2-5 \mathrm{~cm}$ ranged from 20 to 80 and 10 to 60 , respectively (Fig. 6f-j).

Of all feeding guilds, interface feeders (IF) constituted the dominant group in numbers ( 20 to $80 \%)$, followed by subsurface deposit-feeders (SSDF, 10 to $90 \%$ ). The percentage of surface deposit-feeders (SDF) was higher in the bay-mouth and in the inner-shelf (all Mann-Whitney $U$-tests with $\mathrm{p}<0.001$ ), while that of subsurface deposit-feeders (SSDF) was higher in the

\section{Bioturbation potential and vertical distribution}

In the PCA for density-based data, the first 2 PCs explained $90.9 \%$ of the total variance (Table 4 ). The first component ( $60.4 \%$ of total variance) was inversely related to the vertical distribution of individuals and to the ratio of subsurface deposit-feeeders to total surfacefeeders. PC2 (30.5\% of total variance) was inversely related to the contribution of strong bioturbators in relation to the surface-defecators/interface-feeders. This PC axis constitutes an index of 'relative' bioturbation potential, since it does not take total abundance into account. PCA values for the biomass-based data are also shown in Table 4 . The first 2 components explained $82.9 \%$ of the total variance: PC1 (59.1\% of total variance) was directly related to the contribution of burrowing predators, potentially strong bioturbators to the assemblage (equivalent to the PC2 of density-based 

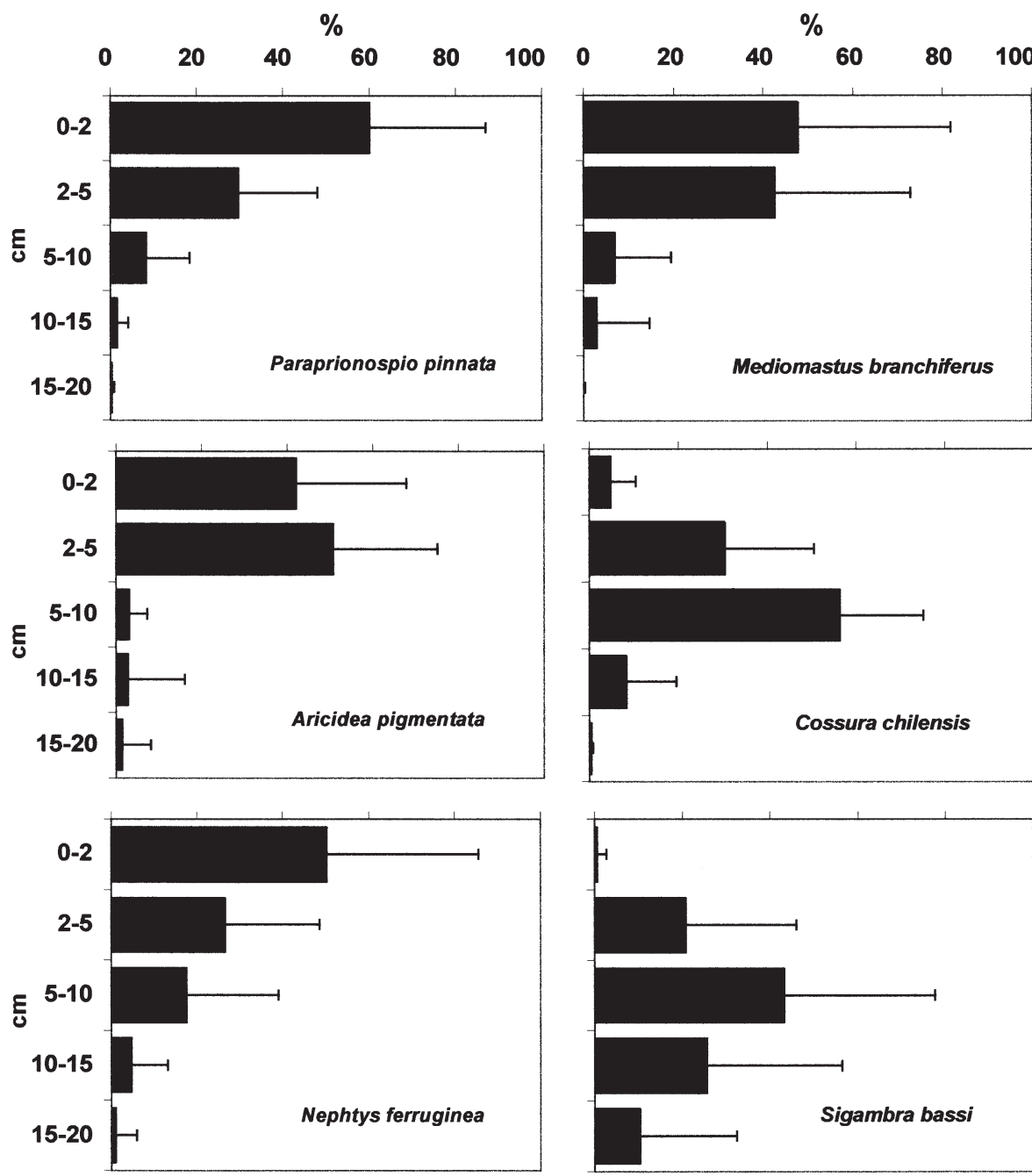

Fig. 5. Average vertical relative distribution (based on density) of commoner species of macrofauna off Concepción (means +1 SD) data); PC2 (23.7 \% of total variance) represented mainly the vertical penetration of macrofauna in terms of biomass. Because of their low biomass contribution, the loadings of reverse conveyor-belt feeders in the first components are very low (Table 4).

\section{Temporal patterns}

A surface-dwelling fauna dominated numerically at all sites, with the exception of the bay-mouth, in May 1997. The mid-bay biota evolved from a surficial, potentially weak-bioturbating assemblage in May 1997 to an intermediate-dwelling and mixed assemblage in the subsequent samplings, although the initial conditions tended to recur in March 1998. In the baymouth, an intermediate-dwelling, potentially strongbioturbating assemblage was present throughout the study period. The inner-shelf fauna, rather surficial and moderately bioturbating initially, exhibited increased vertical penetration and bioturbation potential over time. The middle- and outer-shelf biotas evolved from a surficial, potentially weak-bioturbating, assemblage to a deep-dwelling assemblage dominated by diffusive bioturbators, although this tendency was weaker for the middle-shelf biota (Fig. 8). In terms of biomass, temporal variation showed basically a similar pattern (data not shown).

Effect of abiotic factors on bioturbation potential and vertical distribution

Table 5 presents the results of a multiple regression of abiotic factors on both density-based and biomassbased first PCs. For density-based data, $70 \%$ of the variance of PC1 was explained by TOC at depth and the $\log$ of chl $a$ at the surface. Higher TOC values at depth and lower organic matter quality at the surface resulted in a relatively deeper density distribution and a higher contribution of subsurface deposit-feeders to the assemblage. On the other hand, $43 \%$ of the vari- 

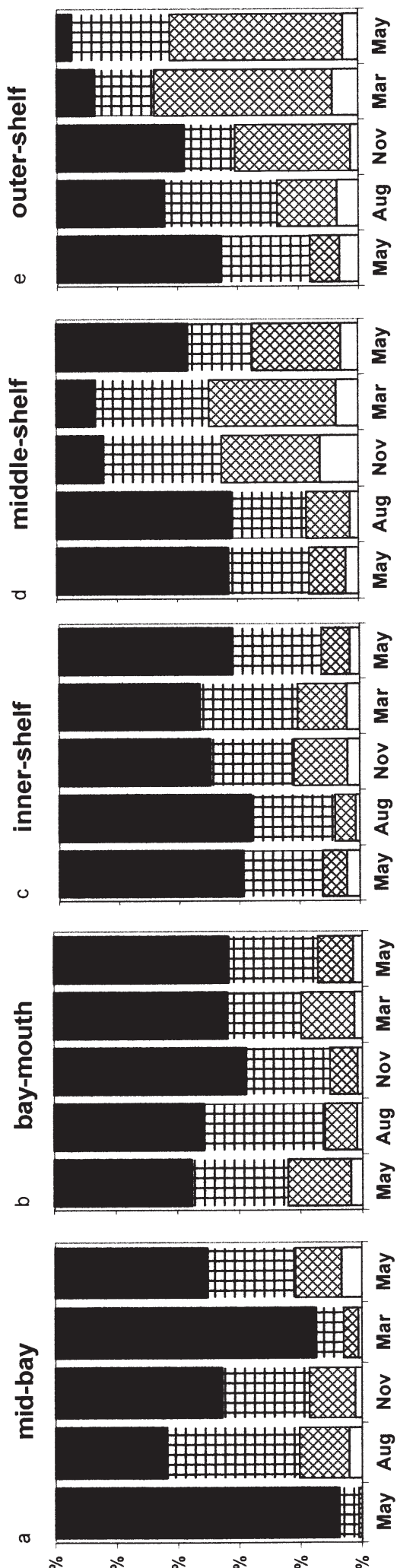

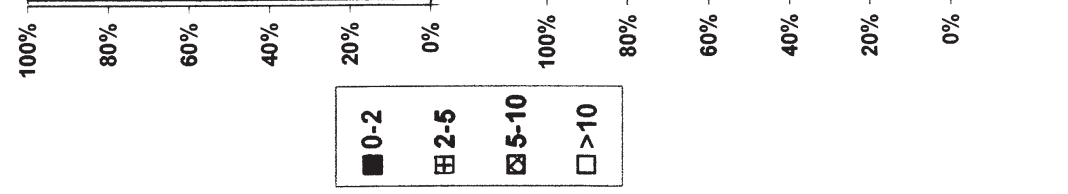

ance of PC2 was explained by BWDO and the log of chl a. In this case, higher surface chl a concentrations and lower BWDO were related to a higher contribution of surface defecators to total density, and hence a lower 'relative' bioturbation potential of the assemblage. For biomass-based data, $46 \%$ of the variance of PC1 is explained by surface TOC and the log of chl a. Here a higher 'relative' bioturbation potential is related to higher contents of TOC and lower concentrations of chl $a$ at the surface. Regression analysis excluding the mid-bay (because of its much higher organic quality) resulted in significant models with the same predictors, but the total explained variance was lower (data not shown). Transformation of the scores of the density-based PC2 and biomass-based PC1 to a positive scale and subsequent weighting by the logs of total numbers and total biomass produced 'absolute' or true bioturbation-potential indexes (Table 6). Multiple regression was also run for both these new variables. In each case, BWDO and chl a were the best significant predictors. Higher BWDO values and lower organic matter quality tended to improve bioturbation potential and vice versa (Table 5).

\section{DISCUSSION}

\section{Environmental setting}

The TOC values determined in this study were in the same range as those reported by Thamdrup \& Canfield (1996) for the same stations in summer 1994, a non-EN year (Gallardo et al. unpubl.). High values of total organic matter measured by loss of ignition $(>10 \%)$ and TOC (>2\%) have been reported for other embayments of the Chilean coast: Mejillones Bay and Arauco Gulf (Baldovinos 1997, Valdés 1998). The chl a concentrations measured in this study (9 to $482 \mu \mathrm{g} \mathrm{g}^{-1} ; 4$ to $37 \mu \mathrm{g} \mathrm{cm}^{-3}$ ) were at least one order of magnitude higher than those reported for bathyal sediments with 


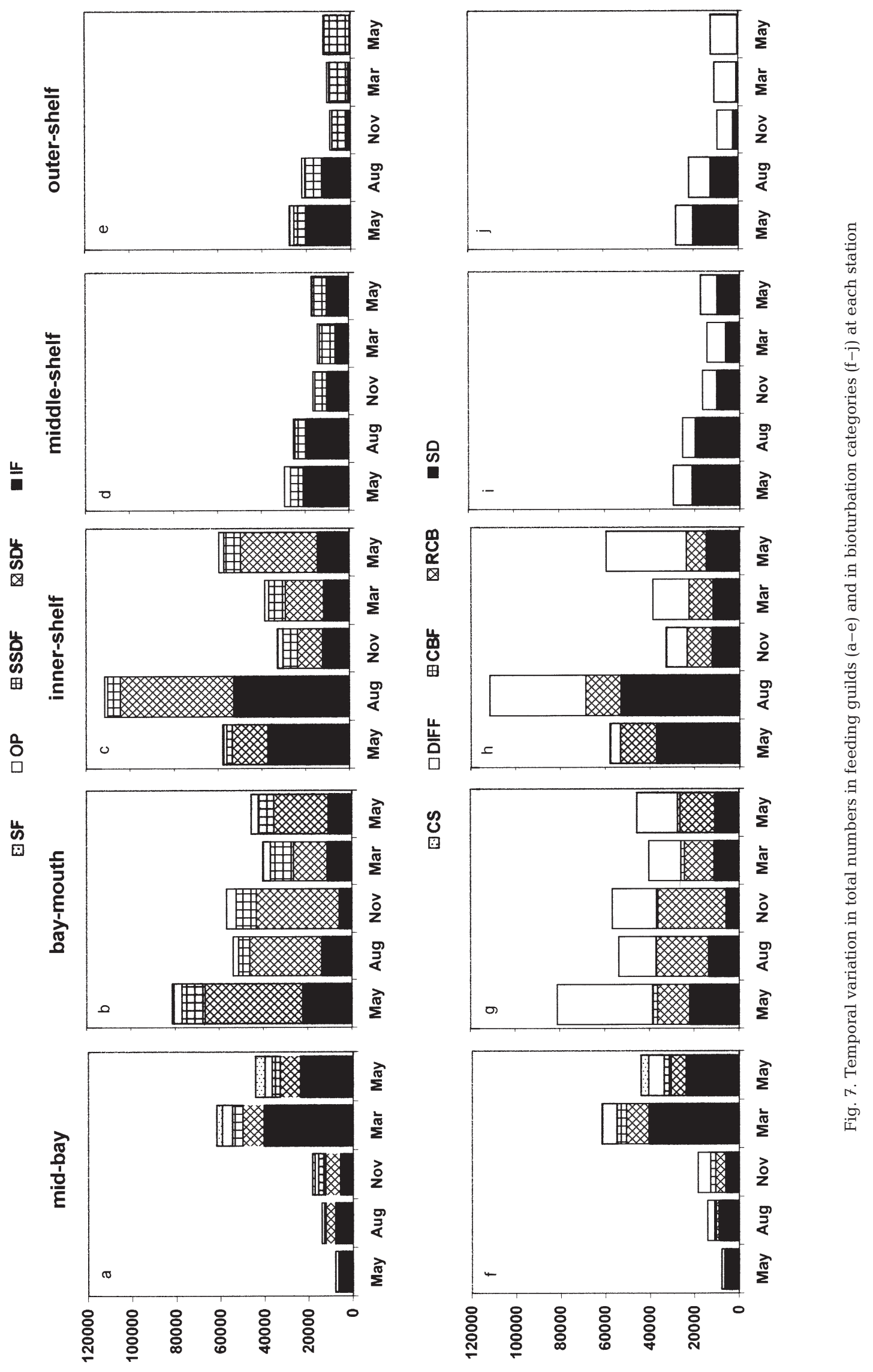


Table 4. Loadings for PCA based on density and biomass data. PCA analysis performed with variance-covariance matrix. Abbreviations as in Table 3

\begin{tabular}{|lcc|}
\hline Variables & PC1 & PC2 \\
\hline Density & & \\
Upper & 0.411 & -0.010 \\
Lower & -0.376 & 0.064 \\
OP & 0.010 & 0.015 \\
SDF & 0.219 & -0.667 \\
SD & 0.300 & 0.593 \\
SSDF & -0.541 & 0.058 \\
CBF & 0.020 & -0.014 \\
Diff & -0.484 & -0.187 \\
RCB & 0.155 & -0.400 \\
Explained variance $(\%)$ & 60 & 30 \\
Biomass & & \\
Diff & 0.615 & -0.090 \\
RCB & -0.006 & -0.029 \\
Upper & -0.192 & -0.691 \\
Lower & 0.131 & 0.630 \\
SDF & 0.081 & -0.174 \\
SD & -0.609 & 0.167 \\
OP & 0.426 & -0.147 \\
SSDF & 0.096 & 0.193 \\
Explained variance $(\%)$ & 59 & 24 \\
& & \\
\hline
\end{tabular}

comparable TOC contents in oxygen minimum zones in the eastern Pacific and Arabian Sea (Levin et al. 1997, 2000). Even though the fluorometric method tends to overestimate chl a concentrations, those recorded in the present study appear to be high enough to exceed those from other sublittoral settings such as the North Sea (Dauwe et al. 1998) and Long Island Sound (Sun et al. 1994), both measured by HPLC. They are also higher than those measured fluorometrically by Radziejewska et al. (1996) off the Mississippi River in surface sediments between 25 and $106 \mathrm{~m}$ depth.

Several authors have used chl $a$ as a tracer of fresh organic carbon in deep-sea sediments (Graf 1989, Cahoon et al. 1994, Pfannkuche 1994, Stephens et al. 1997) and in sublittoral sediments (Sun et al. 1991, 1994, Boon \& Duineveld 1996, Radziejewska et al. 1996). The use of chl a as an indicator of food quality is supported by studies on the growth rates of bivalves parallel to measurements of pigment concentrations in the surface sediments (Grémare et al. 1997, Boon et al. 1998). Chl a and the ratio chl a/TOC were well correlated with porewater $\mathrm{H}_{2} \mathrm{~S}$ resulting from sulfate reduction, the main organic degradation pathway in these sediments (Thamdrup \& Canfield 1996). Thus, both parameters are good indicators of fresh, highly reactive, organic matter. In contrast, $\mathrm{C} / \mathrm{N}$ ratios were poorly but negatively related to organic quality. These results agree with those of Boon \& Duineveld (1996) who found that chl $a$ and polyunsaturated fatty acids were good biomarkers of the quality of near-bottom particulate organic matter, but that $\mathrm{C} / \mathrm{N}$ ratios were related to the amount of refractory material.

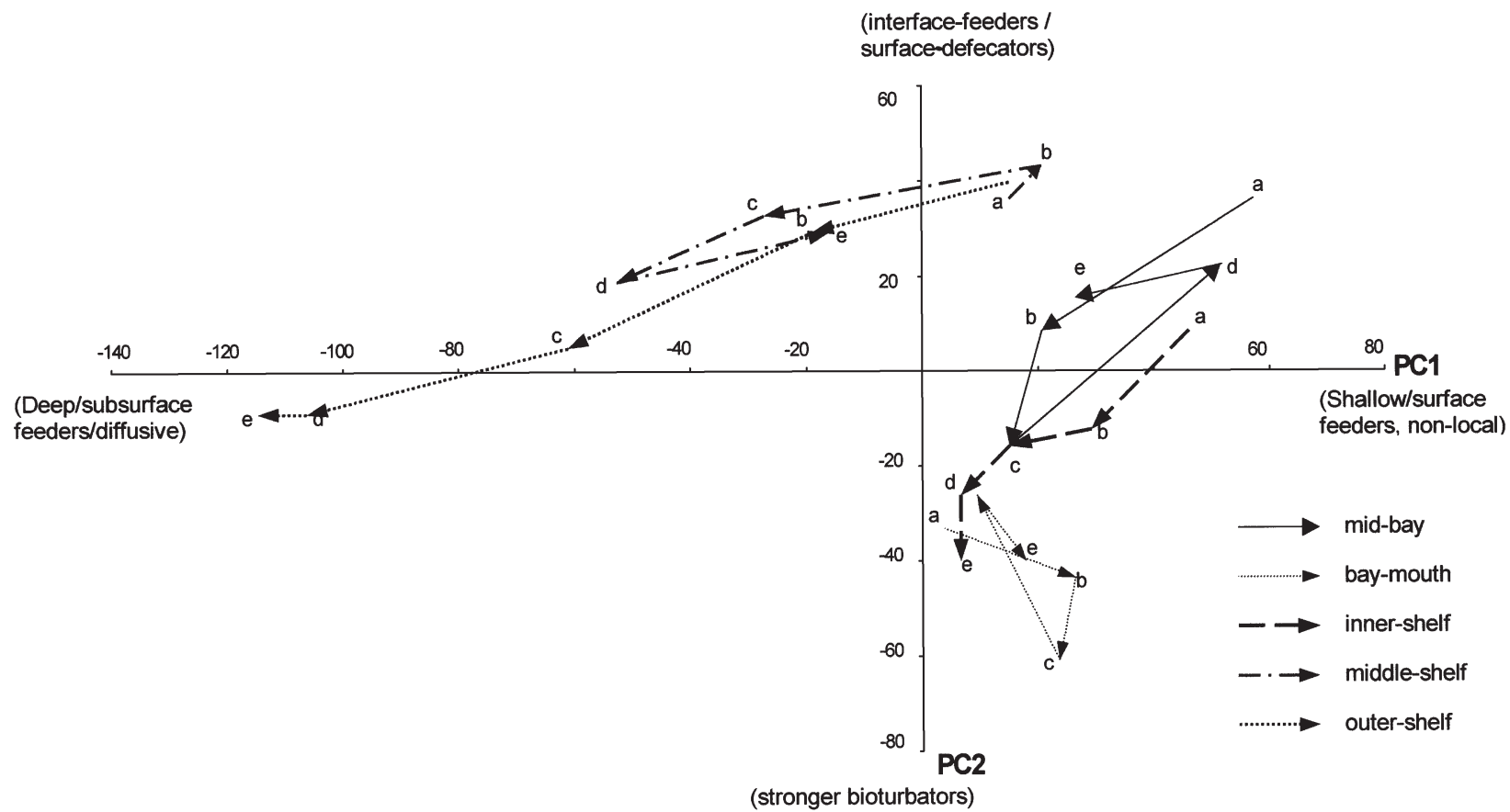

Fig. 8. Plots of stations on a given cruise for PC1 and PC2 derived from density data. Arrows indicate temporal variation: a = May 1997; b = August 1997; c = November 1997; d = March 1998; e = May 1998 
Table 5. Results of multiple-regression analysis. Effects (+/-) of significant Table 4 . NBP = density-weighted bioturbation potential; $\mathrm{BBP}=$ biomassweighted bioturbation potential. Intercepts not shown

\begin{tabular}{|c|c|c|c|c|c|c|c|}
\hline \multirow{2}{*}{$\begin{array}{l}\text { Dependent } \\
\text { variable }\end{array}$} & \multicolumn{4}{|c|}{ Independent variables } & \multicolumn{3}{|c|}{ Model statistics } \\
\hline & $\mathrm{TOC}_{\mathrm{z} 0}$ & $\mathrm{TOC}_{\mathrm{d}}$ & BWDO & $\ln (\operatorname{chl} a)$ & $R^{2}$ & (n) & $\mathrm{p}$ \\
\hline \multicolumn{8}{|l|}{ Density } \\
\hline PC1 & & $\begin{array}{c}(-) \\
<0.0001\end{array}$ & & $\begin{array}{c}(+) \\
0.0003\end{array}$ & 0.70 & (25) & $<0.0001$ \\
\hline PC2 & & & $\begin{array}{c}(-) \\
0.0029\end{array}$ & $\begin{array}{c}(+) \\
0.0139\end{array}$ & 0.43 & (25) & 0.0019 \\
\hline NBP & & & $\begin{array}{c}(+) \\
0.0012\end{array}$ & $\begin{array}{c}(-) \\
0.0102\end{array}$ & 0.48 & (25) & 0.0008 \\
\hline \multicolumn{8}{|l|}{ Biomass } \\
\hline PC1 & $\begin{array}{c}(+) \\
0.0003\end{array}$ & & & $\begin{array}{c}(-) \\
0.0230\end{array}$ & 0.46 & (25) & 0.0012 \\
\hline PC2 & & No mode & is valic & & & & \\
\hline BBP & $\begin{array}{c}(+) \\
0.0278\end{array}$ & & $\begin{array}{c}(+) \\
0.0191\end{array}$ & $\begin{array}{c}(-) \\
0.0009\end{array}$ & 0.44 & (25) & 0.0063 \\
\hline
\end{tabular}
parameters and respective $\mathrm{p}$ values are shown. PC1 and PC2 are those in

environments (Llansó 1992). Our results reveal a key role of the quality of surface organic matter in addition to oxygen availability in dermining the composition of macrofauna feeding guilds with subsurface-feeding fauna preferentially inhabiting sediments with high TOC of low organic quality, and interface-feeding fauna dominating in sediments with highquality organic matter. This aspect wil be discussed further in a later subsection ('Highly reactive sediments and benthicpelagic coupling').

\section{Bioturbation potential and bioturbation rates}

Wheatcroft et al. (1990) postulated that particle biodiffusion is dependent on body size and the density of deposit-feeders. Nevertheless, it is debatable whether bio-

Table 6. Density-weighted bioturbation potential scores. Density-based PC2 scores were transformed to positive scale and weighted by natural logs of density. Higher scores were recorded for bay-mouth and inner-shelf, and also from November 1997 onwards

\begin{tabular}{|c|c|c|c|c|c|c|}
\hline \multirow{2}{*}{ Area } & \multicolumn{3}{|c|}{1997} & \multicolumn{2}{|c|}{1998} & \multirow{2}{*}{ Mean } \\
\hline & May & Aug & Nov & Mar & May & \\
\hline Mid-bay & 214 & 497 & 761 & 418 & 503 & (479) \\
\hline Bay-mouth & 1047 & 1143 & 1348 & 890 & 1065 & (1099) \\
\hline Inner-shelf & 552 & 846 & 782 & 907 & 1087 & (835) \\
\hline Middle-shelf & 216 & 156 & 260 & 375 & 302 & (262) \\
\hline Outer-shelf & 203 & 298 & 502 & 631 & 647 & (456) \\
\hline Mean & 446 & 588 & 731 & 644 & 721 & \\
\hline
\end{tabular}

\section{Distribution of feeding guilds}

Carnivorous macrofauna have been found to be related with coarser, organic-poor sediments (Gaston 1987). Levin et al. (1991) found a diversity of faunal lifeforms, including carnivores, inhabiting the most hypoxic and most organic-rich settings in Volcano 7 , eastern Pacific, but the sediments in their study were coarse. On the other hand, subsurface deposit-feeders have been found to be related to TOC levels (Gaston 1987, Maurer et al. 1994) or to sediments with more refractory material (Flach \& Heip 1996). The shallower distribution of infauna and the higher dominance of tube-building, surface deposit-feeders characterize higher-quality sediments (Dauwe et al. 1998), low oxygen settings (Wheatcroft 1989, Díaz \& Rosenberg 1995, Levin et al. 1997b), and hypoxic periods in estuarine diffusion always constitutes a valid general reflection of bioturbation, since non-local mixing (such as conveyor-belt and reverse conveyor-belt feeding) appears to be a common bioturbation mechanism (Wheatcroft et al. 1990, Blair et al. 1996, Soetaert et al. 1996, Boudreau 1997, Levin et al. 1997a). In this study, bioturbation potential has been inferred from feeding and particle-transport. Lower bioturbation potential results from the dominance of weak bioturbators such as tube-dwelling surface defecators (i.e. mainly Paraprionospio pinnata), and the reverse results from the dominance of potentially non-local bioturbators, subsurface deposit-feeders and/or diffusive bioturbators. It is noticeable that vertical penetration in the sediment and the dominance of specific bioturbation categories or feeding guilds tend to be independent attributes; in fact, they are explained by different PC axes (Table 4). To what degree are changes in faunal composition related to a higher bioturbation potential actually reflected in measured bioturbation rates? Wheatcroft \& Martin (1996) found higher bioturbation rates in organic-enriched sites, but it was not possible to conclude from their data if this pattern was due to a peak of deposit-feeding opportunists (Pearson \& Rosenberg 1978) or to a particular contribution by key species. Smith et al. (2000) found that the ${ }^{210} \mathrm{~Pb}$ mixed layer depth in the Arabian-Sea OMZ was related to faunal lifestyles rather than to vertical penetration of macrofauna. In the same area, Levin et al. (2000) suggested that the dominance of tube-dwelling spionids of the genera Prionospio and Paraprionospio should be translated into reduced mixing rates. We found a basic agreement between the spatial/temporal variation of 
bioturbation potential and bioturbation rates based on chl a profiles (Gutiérrez 2000). A large fraction ( 40\%) of chl a may be subducted non-locally. With the exception of the bay-mouth, the sites exhibited low mixing rates at the beginning of the study $\left(\sim 50 \mathrm{~cm}^{2} \mathrm{yr}^{-1}\right)$ when the assemblage was dominated by surface-defecators. Higher mixing rates were recorded when the contribution of stronger bioturbators increased, especially in the mid-bay and outer-shelf $\left(>200 \mathrm{~cm}^{2} \mathrm{yr}^{-1}\right)$. Significantly higher mixing rates were observed in the midbay in November 1997 and in May 1998, in parallel with higher bioturbation potential (Table 6).

\section{Factors that control bioturbation potential}

We found a negative relationship between the amount of fresh material and bioturbation potential. Pearson \& Rosenberg (1978) predicted that organic enrichment is followed by an increase in the dominance of surface deposit-feeders and a decrease in the macrofaunal vertical penetration into the sediments. Dauwe et al. (1998) found that minimal potential mixing was associated with the highest quality of organic matter. They also found that high amounts of lowquality TOC sediments supported a subsurface-feeding infauna and endobenthic predators. Sediments containing an intermediate quantity and quality of organic matter displayed a higher diversity of trophic groups and a deeper distribution of infauna. In the sublittoral organic-rich sediments off central Chile, both the availability of dissolved oxygen and the quality of organic matter (measured as chl a) are responsible for almost $50 \%$ of the variability of bioturbation potential (Table 5). For a given range in chl a content (e.g. comparing the bay-mouth with the middle-shelf sites), higher BWDO permits a greater contribution of diffusive and non-local bioturbators (bay-mouth; see Figs. 2 $\& 8)$. On the other hand, under a similar oxygen regime (e.g. normoxic conditions in the mid-bay from May to November 1997), a higher bioturbation potential and a deeper relative vertical distribution were observed associated with a decrease in the content of chl a (see Figs. 2 \& 8).

Up to $50 \%$ of the variance of the bioturbation potential is explained in terms of abiotic factors. Part of the remaining variance would result from ecological interactions. Mobile and tube-dwelling adult infauna interfere with each other through habitat modifications related to burrowing and sediment stabilization (Posey 1990, Hall 1994). On the other hand, both BWDO variability and fresh organic matter input are highly episodic, being associated with the short-term variability of the physical regime off Concepción (Arcos \& Navarro 1986). Therefore, part of the unexplained variance may also be due to the different temporal scales of variability in macrofaunal population responses and abiotic factors.

\section{Highly reactive sediments and benthic-pelagic coupling}

Studies on benthic-pelagic coupling in food-limited systems have indicated that fresh organic input results in enhanced benthic activity, including increased non-local bioturbation (Graf 1989, 1992, Jumars et al. 1990, Smith 1992). Consistent with this idea, in the North Sea, Boon \& Duineveld (1998) recorded increased particle-mixing from winter to summer in sediments where organic carbon contents were $<0.1 \%$, but could not detect temporal variation in sediments with a high organic content. Off Concepción, the benthic subsystem supports naturally high organic inputs and is subjected to hypoxic bottomwaters for at least part of the year. Here, fresh organic matter flux does not result in higher bioturbation potential, but the reverse. If bioturbation varies as a parabolic unimodal function of organic matter enrichment, as is the case for bathyal benthic biodiversity (Levin \& Gage 1998), the changes recorded in this study probably correspond to the right side of a parabolic curve. An increase in organic input during spring/summer occurs at the time as severe hypoxia or even anoxia over the bottom, due to intrusion of upwelled oxygen-deficient waters and a higher oxygen demand (Gallardo et al. 1995). Since fresh organic matter is related to sulphide levels in the porewater, there will be increased physiological costs for burrowing and subsurface deposit-feeding species to enable them to tolerate the increasing sulphidic conditions. In contrast, surficial tube-dwelling behavior may permit a certain degree of isolation from the harmful sediment environment. Therefore, hypoxiatolerant, tube-building species, which are also weak bioturbators, are better adapted and may dominate in such conditions. In turn, a higher dominance of tubedwelling surface defecators would lead to enhanced remineralization near the sediment-water interface, while a higher dominance of deep-dwelling subsurface deposit-feeders and non-local mixers would increase mineralization rates in subsurface sediments. This hypothesis is supported by measurements of vertical-fractionated sulphate-reduction rates. Absolute subsurface $(>5 \mathrm{~cm})$ rates measured from November 1997 onwards were higher than those measured in May 1997 in the mid-bay and the 2 deepest sites (Gutiérrez unpubl. data); this is in agreement with a temporal change of macrofaunal vertical distribution and bioturbation potential. 


\section{Sediment oxidation and the role of infauna}

Our PCA results indicate that sediment oxidation tends to be negatively correlated with the quality of organic matter. Our hypothesis is only indirectly supported, since we found that sediments of higher organic-quality (which tend on average to be less oxidized) favor the presence of weak bioturbators such as tube-dwelling surface-defecators.

During upwelling-favorable (i.e. non-EN) years, shelf sediments are still well oxidized and inhabited by an abundant biota, notwithstanding bottom-water hypoxia and a high content and quality of organic matter (Gallardo et al. 1995). These abiotic conditions would result in sulphide accumulation in porewaters. Sulphide removal might be accomplished by Thioploca spp. mats, which are well-developed during such periods (Fossing et al. 1995, Gallardo et al. 1996, unpubl., Otte et al. 1999). In addition or alternatively, an important fraction of sulphide may be removed by bio-irrigation and bioturbation (Thamdrup \& Canfield 1996). Dense tube mats of Paraprionospio pinnata have been found to cover sediments during spring/summer of upwelling-favorable years (Huettel et al. 1995, Vásquez 1999). Despite their weak bioturbation potential, tube mats may favor sulphide oxidation in the surface layer by increasing the diffusion area (Aller 1982). The seasonal relaxation of hypoxia and the decrease of fresh organic input to the sediments is followed by an increase in the population of potentially stronger bioturbators (Vásquez 1999). This community change would enhance sediment oxidation. Burrowing and the formation of feeding-voids subduct oxidized solutes (Díaz et al. 1994) and $\mathrm{Fe}^{+3}$-rich particles, which may remove even more sulphides.

\section{Changes induced by El Niño}

BWDO concentrations in the bay and shelf bottoms were $<0.5 \mathrm{ml} \mathrm{l}^{-1}$ during the spring/summer prior to our study period (Gallardo et al. unpubl.). With only one exception, BWDO levels were $\geq 1 \mathrm{ml} \mathrm{l}^{-1}$ over the entire period of EN in the bay and inner-shelf. In the deeper sites, BWDO increased from values $<0.3 \mathrm{ml} \mathrm{l}^{-1}$ at the beginning of EN (May 1997) to values $>1 \mathrm{ml} \mathrm{l}^{-1}$ at the end. All stations tended to contain lower levels of organic content and quality at the end of EN than at the beginning. The changes in the quantity and quality of the organic matter of the sediment may have resulted from a decrease in primary production in the surface waters of almost 1 order of magnitude that was recorded during EN (L. Farías \& O. Ulloa unpubl.), and a resultant decrease in the fresh organic flux to the bottom.
Mid-bay and outer-shelf sites showed the most drastic changes in vertical distribution and faunal lifestyles related to bioturbation potential. Mid-bay sediments are usually sulphidic, and undergo severe seasonal hypoxia or even anoxia in normal years (Carrasco 1996). On the other hand, outer-shelf bottoms experience permanent hypoxia in normal years (Gallardo et al. 1995). Mass mortalities occur in communities subjected to seasonal severe hypoxia or anoxia (Díaz \& Rosenberg 1995 and references therein). Normoxic conditions $\left(>2 \mathrm{ml} \mathrm{l}^{-1}\right.$ ) may have been present from autumm 1997 until the next summer within the bay. Meanwhile, a reduction in the amount of reactive organic matter occurred at the sediment surface, and sulphide pools decreased. Community-structure changes in the mid-bay followed the same pattern as in coastal sediments off Peru during EN (Tarazona et al. 1988, 1996). An increased abundance of strong bioturbators in midbay sediments was linked to increased macrofaunal density, biomass, species richness (Vásquez 1999), and a deeper vertical distribution. Nevertheless, the interface-feeder/surface-defecator Paraprionospio pinnata still dominated the recolonization of the sediments. This species has been reported to be tolerant of severe hypoxia in estuarine environments (Llansó 1992), and colonizes shallow, usually normoxic bottoms after aperiodic hypoxia and sulphide buildup within the sediments (Harper et al. 1991). Off Concepción, $P$. pinnata appears to be the macrofaunal species best adapted enzymatically to cope with hypoxia (R. González \& R. Quiñones unpubl.).

In the deeper shelf sites, the increase of BWDO from $<0.3$ to $>1 \mathrm{ml} \mathrm{l}^{-1}$ may have triggered changes in both vertical distribution and faunal composition. Levin et al. (1991) suggested that BWDO limits macrofaunal community dynamics at levels below $0.3 \mathrm{ml} \mathrm{l}^{-1}$. Changes in faunal composition and vertical distribution were significant in the outer-shelf but not in the middle-shelf, possibly because of the more refractory and oxidized nature of the outer-shelf sediments. In contrast to the mid-bay, the increase in the contribution of potentially bioturbating species was not accompanied by a higher total macrofauna abundance (Fig. 4). Arntz et al. (1991) also found a non-significant response of macrofaunal density and biomass or a slight decrease during the 1982/1983 EN in the Peruvian shelf $(>40 \mathrm{~m})$. A possible explanation is that during EN populations of the dominant species Paraprionospio pinnata decrease in density, and are not replaced by populations of a successive dominant species in the shelf sediments off Perú (Gutiérrez unpubl.), i.e. respond similarly to higher BWDO and a reduced flux of fresh organic matter to the bottom as shelf populations off central Chile. 
In the bay-mouth and inner-shelf bottoms, which in normal years undergo moderate seasonal hypoxia, temporal changes in bioturbation potential were relatively less pronounced. Higher contributions of strong bioturbators to the assemblage and higher total macrofaunal numbers and biomass resulted in a larger bioturbation potential than in the mid-bay and deeper sites (Table 6). Less oxygen deficiency than over the middle and outer-shelf, and lower organic quality than in the mid-bay sediments, should explain the spatial pattern of bioturbation potential.

\section{CONCLUSIONS}

Dissolved oxygen and organic matter quality play a critical role in determining macrofaunal bioturbation potential of the continental shelf off Concepción. In this habitat, which is characterized by abundant, high-quality organic carbon in the sediments, low BWDO and high-quality organic matter favor the dominance of tube-building, surface-defecators which are weak bioturbators, thus decreasing the bioturbation potential of the macrofaunal community. A higher bulk of organic matter and lower organic quality favor the vertical penetration of infauna and the dominance of subsurface deposit-feeders. During the study period, the 1997/1998 EN increased oxygen levels in the bottom-water and reduced the total and reactive organic carbon flux to the sediments. As a result, both the contribution of bioturbating species and the vertical penetration of infauna increased, most notably in the shallowest (mid-bay) and in the deepest (outer-shelf) sites which, during 'normal' nonEN years experience periodic severe hypoxia/anoxia and defaunation, and permanent environmental hypoxia, respectively.

Acknowledgements. This study was supported by grants from the National Fund for Scientific and Technological Research (FONDECYT Project No. 1971336), a Doctorate Research Project (No. 98.112.047-6) of the Research Directorate of the University of Concepción, and the FONDAPHumboldt Program (CONICYT). We acknowledge Dr Lisa Levin, Dr T. H. Pearson, Dr Silvio Pantoja and 2 anonymous referees for their valuable comments and suggestions. Thanks are also due to Professor Dr Thomas Hoepner, Director of the Institute for Chemistry and Biology of the Sea, University of Oldenburg, and to Professor Dr Wolf Arntz, of the Alfred Wegener Institute for Polar and Marine Research, for their material and moral support. We thank Dr Renato Quiñones (University of Concepción) for providing microtitration equipment for dissolved oxygen analyses, and Ms Silke Schier (ICBM, University of Oldenburg) for her technical assistance in CHN analyses. Finally we acknowledge the crew of the RV 'Kay Kay', without whose help at sea this study could not have been accomplished.

\section{LITERATURE CITED}

Ahumada R (1989) Producción y destino de la biomasa fitoplanctónica en un sistema de bahías en Chile central: una hipótesis. Biol Pesq Chile 18:53-66

Aller RC (1982) The effects of macrobenthos on chemical properties of marine sediment and overlying water. In: McCall P, Tevesz M (eds) Animal-sediment relations. Plenum Press, New York, p 53-102

Arcos D, Navarro N (1986) Análisis de una serie de surgencia para la zona de Talcahuano, Chile (lat. $37^{\circ} \mathrm{S}$ ). Invest Pesq (Chile) 33:91-98

Arntz W, Fahrbach E (1996) El Niño: experimento climático de la naturaleza. Causas físicas y efectos biológicos. Fondo de Cultura Económica, México, DF

Arntz W, Tarazona J, Gallardo VA, Flores LA, Salzwedel H (1991) Benthos communities in oxygen deficient shelf and upper slope areas of the Peruvian and Chilean Pacific coast, and changes caused by EN. Spec Publ Geol Soc Lond 58:131-154

Barnett PR, Watson J, Connelly D (1984) A multiple corer for taking virtually undisturbed samples from shelf, bathyal and abyssal sediments. Oceanol Acta 7:399-408

Blair N, Levin LA, DeMaster D, Plaia G (1996) The short-term fate of fresh algal carbon in continental slope sediments. Limnol Oceanogr 41:1208-1219

Blake JA (1994) Vertical distribution of benthic infauna in continental slope sediments off Cape Lookout, North Carolina. Deep-Sea Res (II) 41:919-927

Boon A, Duineveld GCA (1996) Phytopigments and fatty acids as molecular markers for the quality of near-bottom particulate organic matter in the North Sea. J Sea Res 35: 279-291

Boon A, Duineveld GCA (1998) Chlorophyll a as a marker for bioturbation and carbon flux in southern and central North sea sediments. Mar Ecol Prog Ser 162:33-43

Boon A, Duineveld GCA, Berghuis EM, Van Der Weele JA (1998) Relationships between benthic activity and the annual phytopigment cycle in near-bottom-water and sediments in the southern North Sea. Estuar Coast Shelf Sci 46:1-13

Boudreau B (1997) Diagenetic models and their implementation. Springer-Verlag, Berlin

Cahoon LB, Laws RA, Thomas CJ (1994) Viable diatoms and chlorophyll $a$ in continental slope sediments off Cape Hatteras, North Carolina. Deep-Sea Res (II) 41:767-782

Carrasco FD (1996) Dinámica y vigilancia del macrobentos marino sublitoral sometido a contaminación: el caso de Bahía Concepción, Chile. PhD thesis, Universidad de Concepción

Carrasco FD, Oyarzún C (1988) Diet of the polychaete Lumbrineris tetraura (Schmarda) (Lumbrineridae) in a polluted soft-bottom environment. Bull Mar Sci 42:358-365

Cline JD (1969) Spectrophotometric determination of hydrogen sulphide in natural waters. Limnol Oceanogr 14: 454-458

Dauer DM (1985) Functional morphology and feeding behavior of Paraprionospio pinnata (Polychaete: Spionidae). Mar Biol 85:143-151

Dauwe B, Herman PMJ, Heip CHR (1998) Community structure and bioturbation potential at four North Sea stations with contrasting food supply. Mar Ecol Prog Ser 173: $67-83$

Díaz RJ, Rosenberg R (1995) Marine benthic hypoxia: a review of its ecological effects and the behavioural responses of benthic macrofauna. Oceanogr Mar Biol Annu Rev 33:245-303 
Díaz RJ, Cutter GR, Rhoads DC (1994) The importance of bioturbation to continental slope sediment structure and benthic processes off Cape Hatteras, North Carolina. DeepSea Res (II) 41:719-734

Fauchald K, Jumars PA (1979) The diet of worms: a study of polychaete feeding guilds. Oceanogr Mar Biol Annu Rev 17:191-284

Ferdelman TG, Lee C, Pantoja S, Harder J, Bedout BM, Fosing $H$ (1997) Sulfate reduction and methanogenesis in Thioploca-dominated sediment off the coast of Chile. Geochim Cosmochim Acta 61:3065-3079

Flach E, Heip C (1996) Vertical distribution of macrozoobenthos within the sediment on the continental slope of the Goban Spur area (NE Atlantic). Mar Ecol Prog Ser 141: $55-66$

Fossing H, Gallardo VA, Jørgensen BB, Hüttel M, Nielsen LP, Schulz H, Canfield D, Forster S, Glud RN, Gundersen JK, Ramsing NB, Teske A, Thamdup B, Ulloa O (1995) Concentration and transport of nitrate by the mat-forming sulphur bacterium Thioploca. Nature 374:713-715

Gallardo VA (1977) Large benthic microbial communities in sulfide biota under Peru-Chile subsurface countercurrent. Nature 268:331-332

Gallardo VA (1985) Efectos del fenómeno de 'El Niño' sobre el bentos sublitoral frente a Concepción, Chile. Boln Inst Mar Perú (Vol extraord):79-85

Gallardo VA, Castillo J, Yáñez LA (1972) Algunas consideraciones preliminares sobre la fauna bentónica de los fondos sublitorales blandos de la Bahía de Concepción. Boln Soc Biol Concepción 44:169-190

Gallardo VA, Carrasco FD, Roa R, Cañete JI (1995) Ecological patterns in the benthic macrobiota across the continental shelf off central Chile. Ophelia 40:167-188

Gallardo VA, Carrasco FD, Roa R, Quiñones R, Ulloa O, Cañete Jl, Mesias JK, Sobarzo M, Pineda V, Baltazar M (1996) Benthic detoxification by a bacterial biomat (Thioploca spp.)? Observations on the recruitment of the squat lobster (Pleuroncodes monodon) off central Chile. 9th Southern African Marine Science Symposium, University of Cape Town (Abstracts Book), p 65

Gaston G (1987) Benthic polychaeta of the Middle Atlantic Bight: feeding and distribution. Mar Ecol Prog Ser 36: 251-262

Graf G (1989) Benthic-pelagic coupling in a deep-sea benthic community. Nature 341:437-439

Graf G (1992) Benthic-pelagic coupling: a benthic view. Oceanogr Mar Biol Annu Rev 30:149-190

Grehan A, Scaps P, Desrosiers G, Juniper K, Stora G (1994) Vertical macrofaunal distribution in the soft sediments of the Gulf of St Lawrence and the Scotian continental margin. Vie Milieu 44:101-107

Grémare A, Amouroux JM, Charles F, Dinet A, Riaux-Gobin C, Baudart J, Medernach L, Bodiou JY, Vetion G, Colomines JC, Albert P (1997) Temporal changes in the biochemical composition and nutritional value of the particulate organic matter available to surface depositfeeders: a two-year study. Mar Ecol Prog Ser 150:195-206

Gutiérrez D (2000) Bioperturbación y macrofauna en fondos sublitorales de un área de Surgencias frente a Chile central $\left(36^{\circ} 30^{\prime} \mathrm{S}\right)$ : variación espacial y temporal en el período 1997-1999. PhD thesis, Universidad de Concepción

Hall SJ (1994) Physical disturbance and marine benthic communities: life in unconsolidated sediments. Ocean Mar Biol Annu Rev 32:179-239

Harper D, McKinney L, Nance J, Salzer R (1991) Recovery responses of two benthic assemblages following an acute hypoxic event on the Texas Continental Shelf, northwestern Gulf of Mexico. Geol Soc Spec Pub 58:49-64

Huettel M, Forster S, Klösser S, Fossing H, Gallardo VA, Jørgensen BB (1995) Chemotactic responses in the sediment living sulfur bacteria Thioploca to changes in bottomwater oxygen, nitrate and sulfide concentrations. Max Planck Institute for Marine Microbiology, Bremen (Video)

James FC, McCulloch ChE (1990) Multivariate analysis in ecology and systematics: panacea or Pandora's box? Annu Rev Ecol Syst 21:129-166

Josefson AB (1986) Temporal heterogeneity in deep-water soft-sediment benthos. An attempt to reveal temporal structure. Estuar Coast Shelf Sci 23:147-169

Jumars PA, Wheatcroft RA (1989) Responses of benthos to changing food quality and quantity, with a focus on deposit-feeding and bioturbation. In: Berger $\mathrm{WH}$, Smetacek VS, Wefer G (eds) Productivity of the ocean: present and past. John Wiley \& Sons, London, p 235-253

Jumars PA, Mayer RLM, Deming JW, Baross JA, Wheatcroft RA (1990) Deep-sea deposit-feeding strategies suggested by environmental and feeding constraints. Phil Trans $\mathrm{R}$ Soc (Ser A) 331:85-101

Knap A, Michaels A, Dow R, Johnson R, Gundersen K, Sorensen J, Close A, Howse F, Hammer M, Bates N, Doyle A, Waterhouse T (1993) Bermuda Atlantic timeseries study methods manual (Version 3). Bermuda biological station for research, Inc, US JGOFS

Legendre L, Legendre P (1983) Numerical ecology. Elsevier Scientific Publishing Co, Amsterdam

Levin LA, Gage JD (1998) Relationships between oxygen, organic matter and the diversity of bathyal macrofauna. Deep-Sea Res (II) 45:129-163

Levin LA, Hugget C, Wishner K (1991) Control of deep-sea benthic community structure by oxygen and organic-matter gradients in the eastern Pacific Ocean. J Mar Res 49: 763-800

Levin L, Blair N, DeMaster D, Plaia G, Fornes W, Martin C, Thomas C (1997a) Rapid subduction of organic matter by maldanid polychaetes on the North Carolina slope. J Mar Res 55:595-611

Levin LA, Gage J, Lamont P, Cammidge L, Patience A, Martin C (1997b) Infaunal community structure in a lowoxygen organic rich habitat on the Oman margin. In: Hawkins L, Hutchinson S, Jenson A, Williams J, Sheader $M$ (eds) Responses of marine organisms to their environment. (30th European Marine Biology Symposium). Southampton Oceanography Centre, Southampton, p 223-230

Levin LA, Blair B, Martin C, DeMaster D, Plaia G, Thomas C (1999) Macrofaunal processing of phytodetritus at two sites on the Carolina Margin: in situ experiments using ${ }^{13} \mathrm{C}$-labeled diatoms. Mar Ecol Prog Ser 182:37-54

Levin LA, Gage JD, Martin C, Lamont PA (2000) Macrobenthic community structure associated within and beneath the the oxygen minimum zone, NW Arabian Sea. DeepSea Res (II) 47:189-226

Llansó RJ (1992) Effects of hypoxia on estuarine benthos: the lower Rappahanock River (Chesapeake Bay), a case study. Estuar Coast Shelf Sci 35:491-515

Maurer D, Robertson G, Gerlinger T (1994) Comparison of community structure of soft-bottom macrobenthos of the Newport Submarine Canyon, California and the adjoining shelf. Int Rev Ges Hydrobiol 79:591-603

McPhaden M (1999) Genesis and evolution of the 1997-98 El Niño. Science 283:950-954

Otte S, Kuenen J, Nielsen LP, Paerl W, Zopfi J, Schulz H, Teske A, Strotmann B, Gallardo VA, Jørgensen BB (1999) 
Nitrogen, carbon and sulfur metabolism in natural Thioploca samples. Appl Environ Microbiol 65:3148-3187

Pearson TH, Rosenberg R (1978) Macrobenthic succession in relation to organic enrichment and pollution of the marine environment. Oceanogr Mar Biol Annu Rev 16:229-311

Pfannkuche O (1994) Benthic response to the sedimentation of particulate organic matter at the BIOTRANS station, $47^{\circ} \mathrm{N}, 20^{\circ} \mathrm{W}$. Deep-Sea Res (II) 40:435-449

Posey MH (1990) Functional approaches to soft-substrate communities: how useful are they? Aquat Sci 2:343-356

Radziejewska T, Fleeger JW, Rabalais N, Carman KR (1996) Meiofauna and sediment chloroplastic pigments on the continental shelf off Louisiana, USA. Cont Shelf Res 16: 1699-1723

Rhoads CR, Morse JW (1971) Evolutionary and ecologic significance of oxygen-deficient marine basins. Lethaia 4: $413-428$

Smith CR (1992) Factors controlling bioturbation in deepsea sediments and their relation to models of carbon diagenesis. In: Rowe GT, Pariente V (eds) Deep-sea food chains and the global carbon cycle. Kluwer, Amsterdam, p 375-393

Smith CR, Levin LA, Hoover DJ, McMurtry G, Gage JD (2000) Variations in bioturbation across the Oxygen Minimum Zone in the Northwest Arabian Sea. Deep-Sea Res (II) 47:227-258

Soetaert K, Herman PMJ, Middelburg J, Heip C, deStigter H, Van Weering T, Epping E, Helder W (1996) Modeling ${ }^{210} \mathrm{~Pb}$-derived mixing activity in ocean margin sediments: diffusive versus nonlocal mixing. J Mar Res 54:1207-1227

Sokal RS, Rohlf FJ (1998) Biometry, 3rd edn. WH Freeman and $\mathrm{Co}$, New York

Stephens M, Kadko D, Smith CR, Latasa M (1997) Chl a and pheopigments as tracers of labile organic carbon at the central equatorial Pacific seafloor. Geochim Cosmochim Acta 61:4605-4619

Sun MY, Aller RC, Lee C (1991) Early diagenesis of chlorophyll $a$ in Long Island Sound sediments: a measure of carbon flux and particle reworking. J Mar Res 49:379-401

Sun MY, Aller RC, Lee C (1994) Spatial and temporal distrib-

Editorial responsibility: Lisa Levin (Contributing Editor), La Jolla, California, USA utions of sedimentary chloropigments as indicators of benthic processes in Long Island Sound. J Mar Res 52: 149-176

Swift DJ (1993) The macrobenthic infauna off Sellafield (North-Eastern Irish Sea) with special reference to bioturbation. J Mar Biol Assoc UK 73:143-162

Taghon GL, Greene R (1993) Utilization of deposited and suspended particulate matter by benthic 'interface' feeders. Limnol Oceanogr 37:1370-1391

Tarazona J, Salzwedel H, Arntz WE (1988) Positive effects of 'El Niño' on macrozoobenthos inhabiting hypoxic areas of the Peruvian upwelling system. Oecologia 67:184-190

Tarazona J, Arntz W, Canahuire E (1996) Impact of two 'El Niño' events of different intensity on the hypoxic soft bottom macrobenthos off the central Peruvian coast. PSZN I: Mar Ecol 17:425-446

Thamdrup B, Canfield D (1996) Pathways of carbon oxidation in continental margin sediments off central Chile. Limnol Oceanogr 41:1629-1650

Valdes J (1998) Análisis de Carbono Orgánico en testigos de sedimento de la Bahía de Mejillones del Sur $\left(23^{\circ} \mathrm{S}\right)$. XVIII Congreso Ciencias del Mar, Universidad Arturo Prat (Abstracts Book), Iquique, p 131

Valdovinos C (1997) Patrones de distribución geográfica de la macrofauna bentónica sublitoral del Golfo de Arauco (Chile central). PhD thesis, Universidad de Concepción

Vasquez C (1999) Variación temporal y espacial de la macroinfauna bentónica de Bahía Concepción y Plataforma Continental adyacente $\left(36^{\circ} 40^{\prime} \mathrm{S}, 73^{\circ} 02^{\prime} \mathrm{W}\right)$. Marine Biology thesis. Universidad de Concepción, Concepción

Wheatcroft RA (1989) Comment and reply on 'Characteristic trace-fossil associations in oxygen-poor sedimentary environments'. Geology 17:674

Wheatcroft RA, Martin W (1996) Spatial variation in short term $\left({ }^{234} \mathrm{Th}\right)$ sediment bioturbation intensity along an organic-carbon gradient. J Mar Res 54:763-792

Wheatcroft RA, Jumars PA, Smith CR, Nowell ARM (1990) A mechanistic view of the particulate biodiffusion coefficient: step lengths, rest periods and transport directions. J Mar Res 48:177-207

Submitted: May 3, 1999; Accepted: November 8, 1999 Proofs received from author(s): July 24, 2000 